\title{
Artículos
}

\section{Martirio en la Iglesia Actual Testigos de Cristo en El Salvador}

\author{
P. José María Tojeira
}

\section{Resumen}

El presente artículo expone la experiencia del martirio en la antigüedad y la compara con la de América Latina, concretamente con dos casos específicos: el de Monseńor Romero y el de los jesuitas de la UCA. Monseñor Romero proponía justicia, diálogo, participación, reparto de la riqueza... a partir del pacifismo. Se ocupó de los derechos de los pobres. Asimismo, los jesuitas fueron intelectuales que amaron profundamente la verdad y usaban la razón como arma. Los rasgos característicos de los mártires del pasado, como son la dimensión política del compromiso cristiano, la opción pacífica por la transformación del mundo, la identificación con Cristo, la creación de Iglesia, etc., se manifiestan también en los jesuitas, Monseñor Romero y muchos otros.

\section{Introducción}

Hablar hoy de mártires supone siempre remitirse a la experiencia martirial de la Iglesia. Y, en ese sentido, no podríamos hablar de mártires sin recordar lo que podríamos llamar la experiencia fundante del concepto: las persecuciones de los primeros siglos de cristianismo.

Con la evolución del pensamiento cristiano, lo que era, y sigue siendo, una experiencia primor- dial de fe, y en definitiva una gracia del Señor, se intentó sistematizar conceptualmente. Lo que era fruto inmediato del seguimiento del Señor, comunión con El en su pasión, resistencia frente a las idolatrías de este mundo, libertad frente a poderes que se absolutizaban a sí mismos, testimonio del amor fraterno, se comenzó a definir desde el lado de los perseguidores. Era mártir exclusivamente quien moría víctima del "odio a la fe".

En este artículo propongo retomar a la expe- 
riencia primitiva de martirio y trato de hacer una síntesis de dicha experiencia. A continuación comparo la experiencia primitiva con dos casos de martirio de América latina: el de Monseñor Romero y el de los jesuitas de la Universidad Centroamericana de El Salvador. Prescindiendo del odio a la fe y contemplando, en síntesis, el sentir de la comunidad primitiva sobre el martirio, todo queda muy claro. La motivación del perseguidor no puede ser el elemento que define el martirio y, de hecho, ninguno de los que vivieron el martirio en los primeros siglos lo definía desde ese lugar, aun siendo claramente conscientes del odio que su fe generaba. Incluso, propongo que si en algún momento se quiere utilizar, secundariamente, el criterio de la motivación del perseguidor para definir el martirio, se utilice el término "odio a la humanidad" en vez de "odio a la fe", pues hoy es mucho más sencillo determinar este aspecto que entrar en las intenciones de personas que, muchas de ellas católicas, jamás admitirán que odian a la fe. Todo lo contrario, asegurarán, con frecuencia, que de lo que trataban era de proteger la verdadera catolicidad del rebaño, aun matando a los pastores.

\section{Un concepto de martirio}

El recorrido por los tres primeros siglos del cristianismo, así como el excesivamente breve recorrido histórico posterior, nos permiten iniciar ahora la descripción de los elementos que una definición de martirio debería contener en nuestros días. Aunque en este artículo prescindimos de dicho recorrido, la síntesis que ahora realizamos se apoya en una lectura atenta de la experiencia martirial en los tres primeros siglos del cristianismo. Tratamos ahora de sintetizar ideas de cara a la estructuración de una serie de rasgos en el martirio clásico que nos permitan acercarnos a situaciones martiriales de la actualidad.
No pretendemos con nuestra enumeración de rasgos martiriales formular una nueva definición canónica de martirio. En todo caso, quisiéramos contribuir a la construcción de las bases previas de cualquier definición canónica. Tampoco queremos afirmar que para ser mártir se tengan que cumplir todas las notas y dimensiones que a continuación expondremos. En realidad, muchas de ellas se incluyen unas a otras. Y en la medida en que todas procedan de una vivencia de fe radical, cada una sería más que suficiente para alcanzar la palma del martirio en la medida en que alguien fuera asesinado en el contexto y como consecuencia de las mismas. Lo que tratamos, en realidad, con estas notas, es de acercamos a la realidad martirial desde la experiencia de los tres primeros siglos, sistematizándola en lo que llamamos dimensiones martiriales.

\subsection{Identificación con Cristo en su seguimiento (dimensión mística)}

El martirio es una forma de identificación con Cristo. No la única. Ni siquiera podríamos asegurar que la más meritoria. Pero sí con la gracia especial de asemejarse a Jesús en su muerte de cruz. Ello le da al mártir una capacidad especial de simbolizar la resurrección.

Esta identificación tiene como base un gran amor a la persona de Jesús. El seguimiento trata de historizar la vida y sentimientos de Jesús en nuestra propia existencia, pero incluye, en su afán de unión mística, una tendencia a la imitación, no mimética y dentro de lo posible, del estilo, vida y circunstancias de Jesús. La fe en la resurrección es parte y resultado del amor y del seguimiento. $Y$ en medio de la muerte y el anonadamiento martirial, se manifiesta ya el triunfo de la resurrección de Jesucristo en la propia vida ${ }^{1}$.

1. La muerte, libremente asumida, de los mártires es prueba, como hemos visto, de la fuerza de Dios. Y de alguna manera, esa misma muerte martirial no sólo completa la pasión de Cristo sino los triunfos del Señor. El texto que sigue nos ilustra al respecto: "En efecto, la prueba realmente más fuerte de la resurrección de Cristo es que, habiendo sufrido muerte violenta, muestra tanto poder después de ella, que persuade a los hombres vivos a que desprecien, por confesarle a él, la patria, la familia, los amigos, los parientes y la misma vida, y a preferir a los placeres presentes los azotes, los peligros y la misma muerte. Esto no puede ser la hazaña de un muerto que yace tendido en el sepulcro, sino obra de quien resucitó y vive. Porque, ¿qué razonable explicación cabe que los Apóstoles que con él trataron, convertidos en juguete del miedo, traicionaron todos a su Maestro y le abandonaron huyendo; mas luego que murió, no sólo Pedro y Pablo, sino también Ignacio, que ni siquiera le había visto ni gozado de su trato, mostraron tal devoción y entrega a su persona, que por amor suyo dieron la vida?" (Crisostomo, S. Juan. Panegirico en honor de San Ignacio de Antioquía, en Padres Apostólicos, B.A.C., Daniel Ruiz Bueno, edit, 627). 


\subsection{Orientada a la creación de Iglesia (dimen- sion eclesial)}

Los mártires no sólo son miembros de la Iglesia que, "armados por ella para la batalla", mueren defendiendo sus creencias y doctrina. Son también creadores de Iglesia. No sólo porque la multiplican y contribuyen al auge de las conversiones $o$, en su defecto, de vocaciones a un mismo estilo de trabajo, sino porque participan en la sacramentalidad de la misma Iglesia. La evolución del término "mártir", desde su significado forense hasta el derramamiento de sangre, pasa por un contenido "apostólico". En efecto, los apóstoles se convierten, en los primeros textos del cristianismo, en "mártires-testigos" de la resurrección. Y es a través de ese testimonio martirial referido al Señor como se va creando y extendiendo la Iglesia. El paso a la designación normal del mártir, tal y como hoy la entendemos, no se puede desvincular, históricamente, del testimonio de la resurrección.

La función importante que el martirio desempeñó, en su momento, en el desarrollo de los sacramentos del bautismo, del perdón y del orden, y su relación íntima con la eucaristía, nos reafirma en nuestra convicción. Dimensión de eclesialidad que se desprende también de la afirmación de Colosenses ya citada, según la cual los sufrimientos de los cristianos completan la pasión de Cristo en su cuerpo que es la Iglesia.

En ese cuerpo que se construye desde el amor y cuyos frutos proceden al final del mismo amor. "El amor es el vínculo de la fraternidad, el fundamento de la paz, la firmeza y la tenacidad en la unidad. Es mayor que la fe y que la esperanza y precede a las obras y al martirio"2.

\section{Afirmando valores cristianos y humani- zantes (dimensión moral)}

En el mártir no hay ruptura entre su pasado y su muerte martirial. Incluso, en casos en los que el mártir se suma solidariamente a otros mártires desde la increencia, lo que marca la brecha con la vida pasada es una profunda conversión previa a la decisión de presentarse al martirio. Conversión que hubiera generado un cambio, o una profundización en los valores vitales, si la confesión solidaria no hubiera implicado inmediatamente la

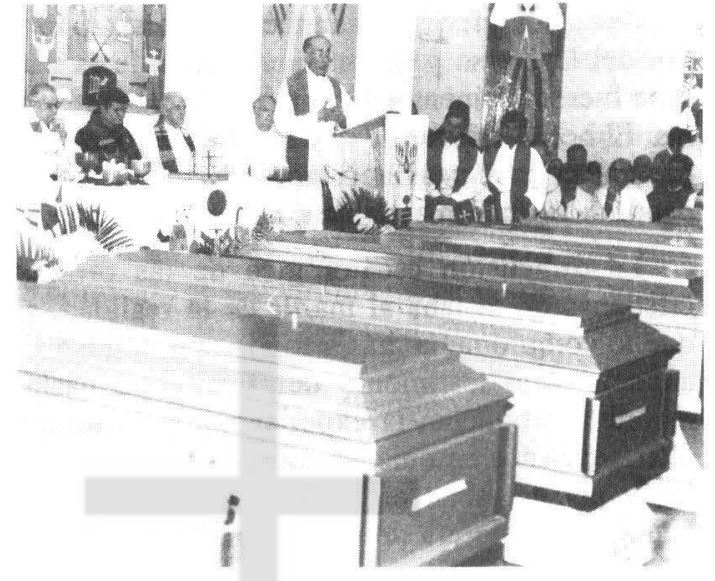

muerte. Incluso, esa muerte es fruto ya de una conversión tan profunda que lleva al recién convertido a ofrecerse a un acto de entrega de la vida por amor a un Señor que comienza a percibir como vivo y presente en los rostros de los torturados y perseguidos. En esa decisión ya existe una opción moral de honda raíz evangélica que lleva a solidarizarse con las víctimas y a enfrentar a los verdugos.

Con sus aciertos y sus pecados, la Iglesia tiene una radical tradición que intenta convertir la utopía del Reino en modelos de transformación social. Desde Hechos 2, $42-46$ y 4, 32-25, hasta la actualidad, esta cadena de experiencias ha unido una fuerte conciencia de comunión entre los hermanos, con vida íntegra y exigencia moral. Los mártires, en general, eran personas que supieron mantener una verdadera coherencia entre vida y Evangelio, convirtiendo vida y muerte en dos facetas de una misma conversión a la persona de Jesucristo.

1.4. Convirtiendo su martirio en kerygma (dimensión profética de anuncio)

Los procesos martiriales atestiguan que, generalmente, los mártires tenían la posibilidad de anunciar su fe y esperanza, aunque fuera en un breve espacio de tiempo. Es evidente que en los relatos de los martirios o pasiones, este anuncio es ampliado y desarrollado por los cronistas y redactores. Pero también es evidente que en el juicio cada mártir disponía de un tiempo breve para res-

2. Cipriano, S. De bono patientiae, XV, PL 4, pp. 631-632. Hay en el texto una clara alusión a I Co 13, 13 . 
ponder a los jueces. El anuncio de Jesucristo Señor del Universo y de la esperanza de la resurrección fueron elementos permanentes en las respuestas. El hecho mismo de que las últimas persecuciones intentaran crear apóstatas, más que mártires, daba un margen mayor para defender la propia fe.

La dimensión escatológica de las promesas cristianas no aislaba al mártir de la realidad, sino que lo comprometía más a fondo con la misma. El anuncio y el testimonio del Evangelio hasta la muerte reproducian la experiencia de la resurrección del Señor en quienes sobrevivían a los mártires y perseveraban en la fe. Y la convicción de que su combate era definitivo y de que se enfrentaba en él, victoriosamente, al anticristo, proporcionaba al mártir un especial coraje en el anuncio y la denuncia.

\subsection{En denuncia de un mundo encerrado en sí mismo (dimensión profética de denuncia)}

Como los profetas, los cristianos se convertían, desde su coherencia, en una denuncia frente a la realidad. Además, cuando eran llevados a juicio, aprovechaban la situación para denunciar el absurdo de una idolatría que presentaba modelos de vida deshumanizadores. Policarpo no duda en decir, mirando a los espectadores de su suplicio, "mueran los ateos" do la petición de su juez que con el término ateo se refería a los cristianos. Y Potamiena blasfema contra los dioses romanos para evitar que su cuerpo sea entregado a los gladiadores 4 . Las Actas de los Mártires y los relatos de sus pasiones están llenos de denuncia y dignidad personal.
Su resistencia frente a las amenazas, las torturas y la muerte era un testimonio práctico-profético de una esperanza que se convertia, automáticamente, en denuncia de una sociedad dispuesta a cobrar (y ofrecer) víctimas humanas a sus ídolos. La seguridad de que los mártires iban a juzgar, con Jesús, a los jueces que los habían condenado, los convertía ya, desde los interrogatorios y los suplicios, en auténticos jueces de una realidad opaca a la trascendencia del amor.

\subsection{Con pretension de transformar la realidad (dimensión política)}

Para el mártir, Jesús es Señor. Señor del Universo y, por supuesto, Señor de la tierra. El mártir es martirizado, casi siempre, por su pretensión de establecer sobre la tierra ese mundo de valores que Jesús trajo desde su amor a todos y su relación con el Padre. Por supuesto que puede haber mártires que parten de valores individuales. Sin embargo, éstos tienen también la pretensión, con sus valores, de incidir en el mejoramiento de la sociedad, aunque sea simplemente con su testimonio de los valores del Reino de Dios.

Pero la gran tradición de la Iglesia está, sobre todo, llena de mártires que no quisieron rendir adoración a ningún tipo de absolutizaciones, especialmente las del poder, la riqueza o el placer. $Y$ que frente a las mismas presentaron, de diversos modos, esperanza, visiones de igualdad fratema, crítica de la cerrazón ante el hermano, organización comunitaria y solidaria. Y siempre con la pretensión de no ser una secta aislada, sino de "transformar la faz de la tierra". El Imperio Ro-

3. Martirio de Policarpo en Padres Apostólicos, o.c., p. 679.

4. Eusebio de Cesarea. Historia Eclesiástica, VI, 5, 2, B.A.C., Argimiro Velasco Delgado (ed) II, p. 357.

5. Jon Sobrino sintetiza la dimensión política de la santidad en el presente con las palabras siguientes: “El santo político es el que una y otra vez echa mano del ideal del reino de Dios y del Dios del reino para configurar la historia y su propia práctica. A pesar de su dificultad mantiene siempre la ultimidad de la primariedad de la vida, de la justicia, de la necesaria lucha, de las necesarias revoluciones y reformas estructurales; pero mantiene también la necesidad de la plenificación de la vida, de la verdad y la libertad, de la reconciliación, de cambiar el corazón del hombre. Mantiene además la aún más difícil simultaneidad de ambos tipos de ideales" (Perfil de una santidad política, Concilium 183, 1983, pp. 342-343). 
mano, construido sobre sucesivas absolutizaciones, y sobre todo en la medida en que se endurecía en las mismas, no podía sino ver como enemigos a los cristianos. $O$, en una segunda alternativa, tratar de incorporarlos a su dinámica.

\subsection{Actuando desde un pacifismo comprometi- do (dimensión práctica)}

El cristiano, como veíamos en Atenágoras, no gusta de la muerte. $\mathrm{Ni}$ siquiera de verla en el enemigo o como juego. Desnudo de la armas de la coerción violenta, utiliza únicamente las armas que ya describía la carta a los Efesios (6, 13-17). La única violencia capaz de ejercitar es la ya conocida en el Antiguo Testamento de amontonar brasas de caridad sobre la cabeza del enemigo ( $\operatorname{Pr} 25,21-22)$ que después citará San Pablo en Rm 12, 20. Si al amor se le puede llamar metafóricamente realidad violenta, ésa es la única violencia que el mártir se permite. Incluso, los insultos a sus jueces, como el "maldito" que aparece en algunos relatos tardíos, no parece que fueran ciertos en boca de los mártires.

Este pacifismo no aísla al mártir de la realidad, sino que le compromete con ella. No lo hace bus- car soluciones irenistas allí donde se juega esa gloria de Dios tan concreta que no es otra cosa sino el hombre vivo (San Ireneo). Le lleva a decir la verdad, parafraseando a Juan Pablo II, sobre la persona humana, sobre el mundo y sobre Dios. Y sobre todo a dar testimonio, con su vida, de esa verdad (Jn 18, 36-37). El mártir, como Jesús, sabe que el mundo se transforma mejor desde la no violencia activa y desde el amor que da la vida por el amigo (Jn 15, 13). por su pretensión de establecer sobre la tierra ese mundo de valores que Jesús trajo desde su amor a todos y su relación
con el Padre.

1.8. Desde la libertad personal y la resistencia (dimensión sicológica)

"Para ser libres nos ha liberado Cristo" (Ga 5, 1), decía Pablo. Y esta libertad la expresaban los mártires en su vida y en los momentos en los que eran juzgados. Especialmente los Padres que nos cuentan sus martirios, retomaron la palabra "parresía", libertad confiadamente evangélica de expresión, para definir la actitud ante los jueces de los cristianos torturados?.

La actitud del cristiano en la vida parte de una profunda confianza en Dios, que libera de los miedos y da fuerza y coraje para decir la verdad de la propia vida donde sea, y para combatir contra los propios autores del temor ${ }^{8}$. Esta confianza, fruto

6. Martirio de los santos Táraco, Probo y Andrónico, en “Actas de los Mártires”, B.A.C., Daniel Ruiz Bueno (ed) 1125.

7. Eusebio utiliza sistemáticamente esta palabra para referirse a la libertad con la que los cristianos respondían a sus jueces. El relato martirial tardío de los santos Táraco, Probo y Andrónico (Acta de los Mártires, o.c., pp. 1112-1113) nos transcribe un diálogo con una síntesis ejemplar de lo que decimos. El diálogo tiene lugar entre el juez Máximo y el mártir Probo:

Máximo: - Me estás hablando como si fueras mi igual.

Táraco: -No, yo no soy tu igual, ni permita Dios que jamás lo sea; sin embargo, tengo libertad ("parresía") para hablar, y nadie me la puede quitar gracias a la fuerza que de Dios me viene por Cristo.

Máximo: - Yo te cortaré de raíz esa libertad ("parresía") de palabra, hombre abominable.

Táraco: - Te repito que nadie me quitará esta libertad, ("parresía"), ni tú, ni tus emperadores, ni Satanás tu padre, ni los demonios a quienes tú, en tu extravío, sirves.

8. Aun en medio de la angustia y del dolor, y aun en medio de una concepción agónica de la existencia que nos lleva a esperar contra toda esperanza, el cristiano tiene una confianza profunda en el triunfo final. Como diría Cipriano, "temer la muerte es de aquel que no quiere ir a Cristo. No querer ir a Cristo es de aquel que no cree que comenzará a reinar con Cristo" (De mortalitate, PL 4, p. 584). 
de la identificación con el Señor Jesús, lleva simultáneamente a la libertad evangélica y a la resistencia ${ }^{9}$ frente a la agresión y la dureza del mal.

\subsection{Con el valor de la semilla (dimensión apos- tólica)}

El apostolado cristiano comienza siempre, y únicamente, después de una conversión. Esta conversión, simbolizada en el bautismo como inmersión en las aguas purificadoras y como resurgimiento a la nueva vida desde las aguas que significan la muerte del pecado, se da en grado sumo en el martirio. Cuando decimos que el martirio es una gracia no queremos decir que es un simple regalo de Dios, sino que es una realidad que está afincada en el orden de la gracia de Dios. Esa gracia que llama, convierte y compromete. No en vano los Padres reconocían en el martirio un bautismo de sangre para quien no hubiera recibido antes este sacramento. Había en el martirio la gracia suprema que puede recibir el cristiano: la identificación final con el Señor.

Y la identificación con el Señor es siempre "apostólica", en el sentido normal que damos al término apostolado, de trabajo en "los campos del Señor" y de "testimonio de su resurrección". Las formulaciones son muchas y variadas. Desde la de "si el grano de trigo no muere, no da fruto, pero si muere dará fruto en abundancia" (Jn 12, 24), hasta la ya citada y célebre de Tertuliano afirmando que la sangre de los mártires "es una semilla". El poder de Dios se manifiesta en la debilidad, y el martirio es un lugar ejemplar y verificador de esa paradoja.

\section{El odium fidei (odjo a la fe)}

Como ya hemos visto, Benedicto XIV insistía, desde su definición canónica del martirio, en el odio a la fe que, de una manera u otra, debería tener el perseguidor. $Y$ establecía, incluso, diversas maneras de probarlo.

\subsection{Los problemas planteados por el término}

En nuestra definición de martirio no hemos mencionado el odium fidei, no porque no lo hayamos encontrado en los perseguidores de los primeros siglos, sino porque de lo que tratamos es de reproducir el concepto que nos transmiten quienes vivieron la experiencia de las persecuciones. Para ellos, el odium fidei no era un elemento definidor del martirio. Al contrario, definían la realidad martirial desde lo positivo de sus actitudes de fe, resistencia, libertad y solidaridad. La identificación con el Señor llevaba no tanto a ver el odio de quienes juzgaban a los cristianos (que era por otra parte sistemáticamente denunciado), sino el amor que reposaba como sustrato poderoso en el compromiso que llevaba al martirio. Como decía S. Cipriano, "en las persecuciones nadie piense cuánto peligro suponga el diablo, sino, sobre todo, considere cuánta ayuda nos brinda Dios"10.

Por otra parte, en muchas de las persecuciones actuales es sumamente difícil probar el odio del perseguidor, al menos con la claridad con que se podía probar en regímenes o sociedades en que la religión estaba legalmente proscrita. En general, los modernos perseguidores suelen negar que persigan a la Iglesia. E, incluso, se esmeran en buscar aliados dentro de la Iglesia que nieguen situaciones de persecución ${ }^{11}$.

9. Es interesante observar cómo autores contemporáneos recuperan el término resistencia al hablar del martirio enmarcado en las luchas de los pobres por su liberación. Juan Hemández Pico, en El martirio hoy en América latina, Concilium 183,1983 , p. 369 , utiliza la palabra resistencia repetidas veces, convirtiéndola en clave del nuevo estilo de martirio que pretende no sólo el testimonio de Jesús como Señor sino el acercamiento del Reino a esta tierra en estructuras de justicia. De hecho, el autor pone "la conciencia de la compatibilidad entre resistencia y seguimiento de Cristo" como fermento de las luchas de los oprimidos.

10. Epistola ad Fortunatum, X, PL 4, pp. 664-665.

11. Por mencionar sólo dos ejemplos valga recordar que en los países del Este europeo, bajo control de la ideología marxista, surgían con frecuencia grupos de sacerdotes que respaldaban al gobiemo y negaban una persecución más que evidente. En El Salvador, tras la muerte de los jesuitas, y coincidiendo con una campaña de encubrimiento de los autores del asesinato por parte del gobierno, dos obispos y un sacerdote viajaron a Roma tratando de denigrar al entonces arzobispo, Monseñor Rivera, y sus esfuerzos por esclarecer la verdad. Ampliaremos esto más adelante. 


\subsection{Hacia nuevos términos con dimensión operativa}

Hoy en día, la noción del odium fidei, al menos en su dimensión social, debería sustituirse, más en coherencia con el pasado cristiano, con lo que podíamos llamar "odio a la humanidad". En efecto, los gobiernos son hoy sistemáticamente violadores de los derechos humanos, los que habitualmente persiguen a las Iglesias, entre otros sectores. Y son, a su manera, los que más se parecen a los idólatras de antaño, dispuestos a sacrificar las vidas inocentes de quienes se oponían a sus idolatrías $^{12}$.

En el Imperio Romano, la religión no sólo legitimaba al estado, sino que era una de las bases y fundamentos de su estructura autoritaria. La piedad romana debía tributarse, como ya hemos dicho, no sólo a los dioses, sino también al emperador. El genio del emperador, por el que se pedía a los cristianos que juraran, era una divinización de las virtudes imperiales. $Y$ era, al final, a esa estructura religiosa absolutizante a la que se inmolaban las victimas cristianas.

Hoy son las modernas idolatrías del poder en sí mismo, de la riqueza, de las razones de Estado como absoluto final, las que legitiman prácticas autoritarias que llevan a sacrificar cruentamente a hombres y mujeres contra todo derecho establecido. "Un mundo que no excluye frontalmente a la fe, sino la domestica idolátricamente pervirtiéndola en adomo y justificación de la opresión e injusticia, no va a matar por odio directo a la confesión de la fe, sino a los que intenten autentificar la fe, realizándola en el seguimiento efectivo de Jesucristo, en la solidaridad transformadora con los pobres, en el desenmascaramiento profético de la opresión y la idolatría"13.
En la actualidad todavía hay cristianos que son asesinados por su fe en cuanto estricta denominación religiosa. Pero son casos especiales y en países donde impera el fanatismo o el fundamentalismo religioso ${ }^{14}$. Sin embargo, y sin menospreciar la dimensión martirial de dicho tipo de muerte, hay que reseñar que son muchos más los que hoy mueren en países de tradición cristiana o no cristiana, a causa de los compromisos que la fe implica en materia de derechos humanos.

En efecto, en regímenes que pueden ir desde el Timor Oriental invadido hasta la democracia formal de Guatemala, los cristianos se vuelven sospechos, e incluso mueren asesinados, no tanto por la fe que profesan, sino por los compromisos que la misma implica. Compromisos asumidos desde la fe cristiana pero que a veces son simplemente humanitarios, como dar de comer al hambriento, sin mirar credos políticos, o responden a derechos básicos como el de la libre asociación o sindicalización. No digamos de aquellos que se comprometen sistemáticamente con la defensa de los derechos humanos y con la promoción de la paz o la defensa de la vida, que son automática-

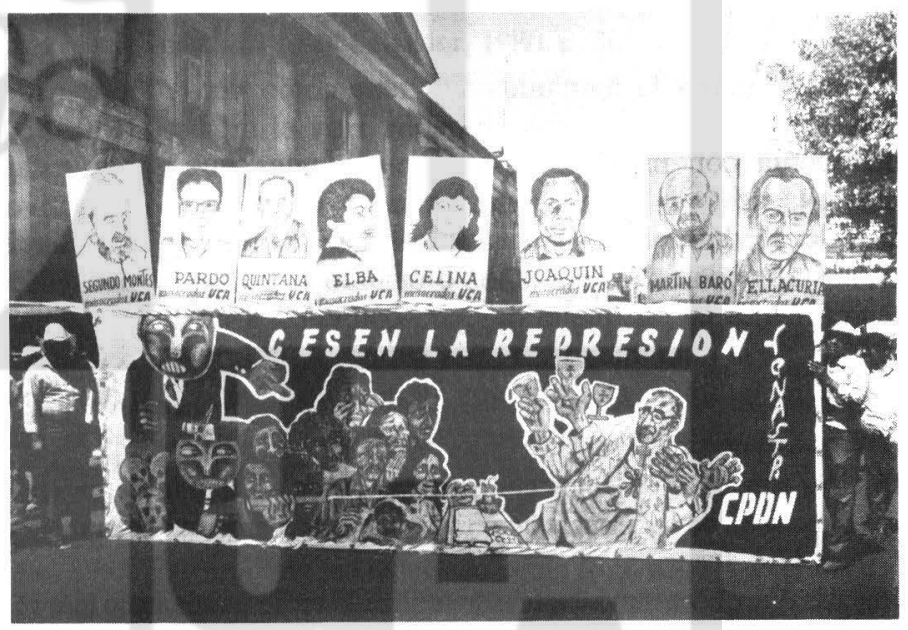

12. El caso de los nazis puede ser un ejemplo claro. Probado el "odio a la humanidad" a partir de sus prácticas de exterminio inspiradas en un racismo delirante, no sería necesario probar el odio a la fe cuando se tratara del caso de un cristiano que desde la solidaridad con las víctimas se opusiera pacíficamente al régimen y fuera por ello asesinado.

13. Jiménez Limón, Javier. "Sufrimiento, muerte, cruz y martirio", en Mysterium Liberationis, Tomos I y II, Ellacuría y J. Sobrino (eds.), Madrid, 1990, p. 492.

14. El caso típico sería el de las religiosas asesinadas en Argelia por fundamentalistas islámicos. 
mente mirados como opositores políticos por regímenes de cuño autoritario, son denigrados públicamente, hostigados y perseguidos, y con relativa frecuencia asesinados. Todo ello en medio de una insultante propaganda de medios de comunicación excesivamente ligados a intereses políticos y económicos empeñados en mantener situaciones de control político y beneficio privado reñidos con la justicia.

Se podrá argüir que no por ser asesinado por los derechos humanos se es automáticamente mártir cristiano. Pero es evidente que quienes asumen este compromiso en razón de su fe cristiana, están convirtiendo su fe en símbolo muy concreto del doble y básico mandamiento de amar a Dios sobre todas las cosas y al prójimo como a sí mismo (Lc 10, 25-28). Y dan, en ese sentido, la vida no sólo por una "virtud cristiana" sino por el compromiso fundamental del cristianismo de amar al hermano ${ }^{15}$.

Este "odio a la humanidad"16 tiene como ventaja que es claramente comprobable. Hoy el mundo cuenta con instituciones internacionales que más allá de toda duda racional pueden establecer cuándo se dan situaciones sistemáticas de violaciones a los derechos humanos o cuándo se cometen crímenes de los que el derecho comienza a llamar de "lesa humanidad". Y, por supuesto, la Iglesia tiene también mecanismos para investigar y conocer cuándo el compromiso con los derechos fundamentales se toma desde una opción de fe y cuándo es resultado de otras opciones, muy respetables y meritorias en sí mismas, pero no específicamente cristianas ${ }^{17}$.

\section{Las gestas innumerables de la actualidad}

En nuestra historia actual, plagada de guerras y conflictos sociales, los cristianos viven, como tantos otros habitantes de este mundo, en medio de la amenaza. Sin pretender hacer comparaciones (al igual que se puede hablar de "cristianos anónimos", deberíamos hablar también de auténticos "mártires anónimos" entre los no cristianos), lo cierto es que con frecuecia los cristianos no sólo son abatidos y sacrificados por la furia de las guerras sino, muchas veces, por su propio testimonio.

En América Latina los casos son innumerables. Se pueden contar campesinos y campesinas asesinados por dar hospedaje, basados en su fe (Mt 25, 35), a personas empobrecidas que buscaban refugio fuera de sus países, ya que huían de operativos de tierra arrasada lanzados por ejércitos sin conciencia. Celebradores de la Palabra torturados y desaparecidos por el único delito de leer y comentar la Palabra de Dios en sus aldeas ${ }^{18}$. Mujeres que participaban en asociaciones comunales para el mejoramiento de sus barrios o aldeas, con-

15. Por supuesto hablamos del hermano no en el sentido del miembro de la misma fe o congregación, sino en la dimensión de la hermandad universal que se deriva de la también universal paternidad de Dios, que Jesús afirmó con tanta fuerza.

16. Más que el concepto expresado, utilizado en su paralelismo con el odium fidei, queremos defender la idea que en él subyace. Hoy a los cristianos se les mata por su compromiso vital más que por la formulación de su fe. Y ese compromiso es evidentemente un compromiso de humanidad.

17. No se trata aquí de incluir en el concepto de mártir a todos aquellos que mueran por alguna causa buena en sí misma. La distinción de Benedicto XIV, de mártires ante Dios y ante la Iglesia, podría utilizarse aquí y ahora en otro sentido. Mártir especificamente cristiano es aquel que muere violenta e injustamente en el compromiso derivado de su fe. Mártir ante Dios es todo aquel que es asesinado por su defensa pacífica de los valores de la conciencia y de la creación sin que medie la fe explícita cristiana. La Iglesia, aunque crea en el mérito y la salvación de este tipo de personas, no debería proclamarlas mártires. Y ello no por su carencia de fe, sino por respeto a su fe u opciones diferentes.

18. Los torturados que después sobrevivieron, si hubieran vivido en el siglo III, hubieran merecido de Cipriano, o del autor de los cánones de Hipólito, sin lugar a dudas, la calificación de auténticos sacerdotes de la Iglesia. 
cientizadas y movidas a ello desde su propia fe, que fueron "desbarrigadas", por usar una palabra de Bartolomé de Las Casas narrando la brutalidad de los conquistadores, si estaban embarazadas, o violadas repetidas veces antes de alcanzar una muerte liberadora. Algunos "testigos" de excepción, usando el término en la doble acepción de su significado, como Monseñor Romero, hablaban de la multitud de nuevos mártires con tonos que nos recuerdan claramente a los antiguos testigos de las primeras persecuciones: "Sería imposible enumerarlos, pero recordemos, por ejemplo, a Filomena Puertas, Miguel Martínez y a tantos otros, queridos hermanos, que han trabajado, que han muerto y que en la hora de su dolor, de su agonía dolorosa, mientras los despellejaban, mientras los torturaban y daban sus vidas, mientras eran ametrallados, subieron al cielo"19.

Más documentados en sus martirios, monjas, sacerdotes y obispos, se unen a esa "masa cándida"20. En profunda semejanza a los tres primeros siglos, no es el clero en América Latina el que sufre prioritariamente las consecuencias de la persecución, sino los hombres y mujeres del pueblo que poblarían, si sus nombres se hubiesen apuntado, los nuevos santorales. Triste sería, parafraseando a Monseñor Romero, que la Iglesia no tuviera mártires entre religiosos, sacerdotes y obispos, cuando los pobres son masacrados y el martirio florece entre los sencillos.

Sin querer negar ese protagonismo popular en el campo martirial, analizaremos algunos casos más documentados que corresponden a figuras vinculadas con servicios especiales en el interior de la Iglesia. En particular, y sobre todo, el caso de Monseñor Romero. Se trata, al mismo tiempo, de una figura profundamente vinculada al sentir popular. El es para muchos, en El Salvador especialmente, pero también en otras partes, símbolo consciente de un auténtico y anónimo testimonio de martirio colectivo.

El método que seguiremos en este análisis será simple y breve. Nos limitaremos en primer lugar a El Salvador. Veremos el caso de Monseñor Romero, haremos una breve reflexión sobre su pensamiento, recorreremos narrativamente el informe "De la locura a la esperanza"21, y finalmente esta-

19. Romero, Oscar Arnulfo, Monseñor. Su pensamiento, Tomos I-II, San Salvador, 1980, p. 301. El pensamiento de Monseñor Romero, especialmente sus homilías, están agrupadas en una colección de siete tomos (el primero lleva la numeración I-II) editada por el Arzobispado de San Salvador. En nuestras citas nos referiremos a Monseñor Romero con las siglas $\mathrm{OR}$, y cuando citemos textos de Su pensamiento, nos limitaremos a poner el tomo, la fecha de edición si no está puesta anteriormente, y la página.

20. El término significa grupo vestido de blanco, referido en ocasiones a diversos conjuntos de mártires y haciendo referencia a los "degollados a causa de la Palabra de Dios" que piden justicia y a los que se les dice que esperen "todavía un poco" mientras se les da una vestidura blanca (Ap 6, 11). Esta ampliación del concepto del martirio a las circunstancias históricas la acepta claramente Fisichella, R. Martirio, Diccionario de Teología Fundamental, R. Latourelle (ed), Madrid, 1992, al poner el amor cristiano como base del compromiso con los derechos humanos y con la justicia: "Si se asume este horizonte interpretativo, resulta claro que el mártir no se limita ya a unos cuantos casos esporádicos, sino que se le puede encontrar en todos aquellos lugares en los que, por amor al evangelio, se vive coherentemente hasta llegar a dar la vida, al lado de los pobres, de los marginados y de los oprimidos, defendiendo sus derechos pisoteados" (868). Nuestro trabajo ha explicitado valores experienciales, que parten de la fe y el amor cristiano, y que se reproducen en una especie de paralelismo entre los mártires de los primeros siglos y los de la actualidad. Al final, la conclusión es idéntica a la del autor citado.

21. De la locura a la esperanza, Naciones Unidas, 1993. Este informe fue redactado como fruto de los Acuerdos de Paz entre el Gobierno de El Salvador (GOES) y el Frente Farabundo Martí para la Liberación Nacional, (FMLN). Los tres comisionados responsables de la redacción final del Informe fueron nombrados por las Naciones Unidas. A la confiabilidad que puede dar un informe redactado bajo el patrocinio de las Naciones Unidas y encomendado a un grupo de profesionales de reconocida competencia, se suma, desde el punto de vista cristiano, la presencia de personalidades vinculadas al compromiso eclesial con los Derechos Humanos. Belisario Betancourt, uno de los tres Comisionados, pertenecía en el momento de la investigación a la Comisión Pontífica de Justicia y Paz. Patricia Tappatá de Valdez, Secretaria Ejecutiva de la Comisión, había sido durante diez años (1977-87) Directora del Departamento de Derechos Humanos de la Comisión Episcopal de Acción Social del Perú. Muchos otros eran católicos practicantes y conocedores de la vida de la Iglesia. Entre las personalidades no cristianas sobresale Thomas Buergenthal, sobreviviente del Campo de Concentración de Auschwitz, profesor universitario de Derecho Internacional, que ejerció un tiempo como Vicepresidente (198385) y después como Presidente (1985-87) de la Corte Interamericana de Derechos Humanos. En las citas utilizo la edición privada de las Naciones Unidas que circuló pocos días antes de su publicación el 15 de marzo de 1993. Posteriormente, la revista ECA de El Salvador lo publicó en edición especial. 
bleceremos una comparación con el concepto de martirio que hemos sugerido. Tras esto haremos también una aplicación muy breve al caso de los Jesuitas asesinados en El Salvador22.

\section{Monseñor Romero}

\subsection{Los hechos}

El caso de Monseñor Romero ocupa un lugar especial en el informe de la Comisión de la Verdad. No sólo es un hecho individual que conmovió a la sociedad salvadoreña y a la sociedad internacional, según afirmación del propio informe, sino que está seleccionado como el caso que ejemplifica "el patrón sistemático de violencia" ${ }^{23}$ de los escuadrones de la muerte.

La Comisión comienza su descripción del caso diciendo que "Monseñor Romero se había erigido en un reconocido crítico de la violencia y la injusticia y, como tal, se le percibía en los círculos civiles y militares de derecha como enemigo peligroso. Sus homilías irritaban profundamente a estos círculos por cuanto incluían recuentos de hechos de violaciones de derechos humanos" 24 .

Antes de su asesinato hubo agresivas campañas de prensa contra su persona, especialmente publicadas en El Diario de Hoy. Se le llamaba "Arzobispo demagogo y violento... (que) estimuló desde la catedral la adopción del terrorismo". O, incluso, un mes antes de su muerte se decia, teniéndole a él en cuenta, que "será conveniente que la Fuerza Armada empiece a aceitar sus fusiles"25.

Antes de su muerte recibió numerosas advertencias y amenazas de muerte "y en virtud de esa situación prefirió que sus colaboradores no lo acompañasen en sus salidas, para evitar riesgos innecesarios" 26 . Pocos días antes de su muerte, cerca del altar mayor, se encontró una bomba. Y, finalmente, el 24 de marzo de 1980 fue asesinado mientras celebraba Misa en la Capilla del Hospital de la Divina Providencia. El tirador disparó una sola bala desde fuera de la Capilla, sin salir del automóvil.

Tras la exposición de pruebas, el informe termina asegurando que "existe plena evidencia de que el Mayor Roberto D'Aubuisson dio la orden de asesinar al Arzobispo y dio instrucciones precisas a miembros de su entorno de seguridad, actuando como escuadrón de la muerte, de organizar y supervisar la ejecución del asesinato"27. Participan también en el asesinato dos capitanes. La Corte Suprema, posteriormente, asume un rol activo impidiendo la extradición de uno de ellos desde Estados Unidos a El Salvador con el fin, o al menos el resultado, de encubrir el asesinato de Monseñor Romero.

\subsection{El pensamiento de Monseñor Romero}

Para lo que nos interesa dividiremos esta exposición en apartados muy breves sobre el pensamiento de Monseñor en torno a la situación sociopolítica de El Salvador, y los temas más relacionados con su pensamiento en tomo al martirio.

\section{A. La realidad nacional}

A Monseñor Romero le tocó vivir una época de creciente y enfrentada violencia en El Salvador. Con el Poder Ejecutivo y el resto de las instituciones estatales controladas por un partido aliado al Ejército, con dos elecciones fraudulentas en 1972 y 1976, con un país con varios años de crecimiento económico ininterrumpido que no hacía sino dejar más patentes las diferencias sociales y con unas organizaciones populares revolucionarias en

22. Hemos elegido estos dos casos porque ambos se encuentran en las fronteras, de arranque y de finalización, de una guerra fratricida que causó en torno a los 80,000 muertos. Como dice el informe De la locura a la esperanza, 4, "la bala expansiva que estalló en el pecho de Monseñor Romero cuando oficiaba la misa el 24 de marzo de 1980 en una Iglesia de la capital, es la cruda síntesis de la pesadilla que atravesó El Salvador durante la guerra. Y el asesinato de los seis sacerdotes jesuitas una década más tarde, fue la crisis final de un comportamiento delirante que había inficionado la institución armada y los más hondos repliegues de una parte de la dirigencia nacional".

23. De la Locura a la esperanza, o.c., pp. 10 y 132.

24. De la locura a la esperanza, o.c., p. 133.

25. Ambas citas corresponden al Diario del Hoy y aparecen en De la locura a la esperanza, ibíd.

26. Ibid.

27. Ibíd, p. 138. El Mayor D'Aubuisson estaba muy vinculado a la oligarquía terrateniente salvadoreña y fue fundador, posteriormente, del hoy gobernante partido ARENA. 
auge, Monseñor Romero comienza su pastoreo de la arquidiócesis de San Salvador en tiempos recios y difíciles. Poco después de su toma de posesión fue asesinado el primer sacerdote de una larga lista, el P. Rutilio Grande, por su apoyo a los campesinos de la parroquia rural en la que trabajaba.

Ante la violencia institucionalizada, Monseñor Romero tenía que hablar, analizar y proponer. Para él los conflictos tenían una triple base. La idolatria de la riqueza sumía a las mayorías salvadoreñas en una pobreza injusta, violenta en sí misma y fuente de otras violencias. La idolatría de la seguridad nacional, además de que "institucionaliza la inseguridad de los individuos", impedía la participación popular en los mecanismos democráticos que podrían ofrecer posibilidades de cambio social. Y la idolatría de la organización supeditaba valores de personas a valores grupales hasta extremos contrarios a la dignidad de la persona humana. Sobre este último punto añadía que si bien la organización de los pobres es buena, deben evitarse estilos organizativos que no tengan en cuenta los valores personales o procedan despóticamente contra sus miembros ${ }^{28}$.

Frente a esta realidad, Monseñor Romero proponía justicia, diálogo, participación, reparto de la riqueza, escuchar los justos clamores del pueblo... Y todo desde un diáfano pacifismo. La única violencia que admitía era "la violencia del amor, la de la fraternidad, la que quiere convertir las armas en hoces para el trabajo"29. De hecho, no hubo familia, estuviera en el bando que estuviera, que solicitara ayuda y no recibiera una palabra de apoyo o de mediación, si ésta última era posible, de parte de Monseñor Romero. Desde los sectores populares que pedían libertad de expresión y manifestación, hasta miembros de familias poderosas que acudían al obispo cuando sus parientes eran secuestrados.

\section{B. El problema de la violencia}

Aunque Monseñor Romero se ocupó especialmente del problema de la justicia y de los dere-

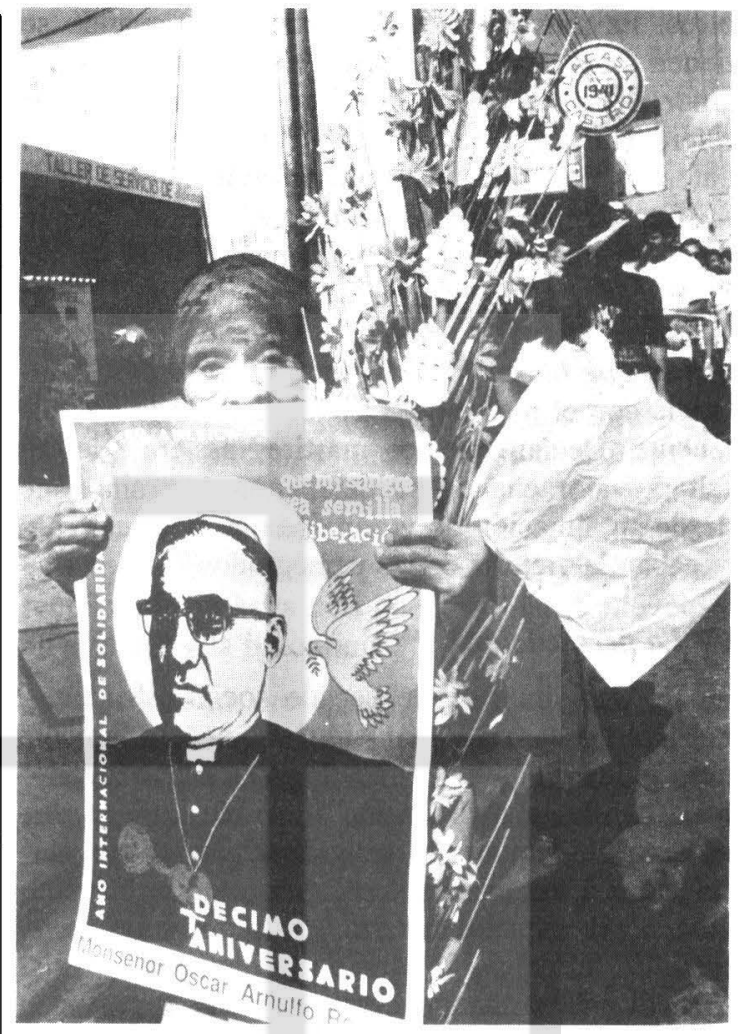

chos de los pobres, nosotros nos fijaremos más en otra serie de temas, también tratados por él, que tienen relación directa con su interpretación del compromiso cristiano con la justicia en medio de una situación difícil. El primero de estos problemas era la violencia.

Frente a la violencia de la injusticia institucionalizada surgía, cada vez más fuerte, la posibilidad y la doctrina de la necesidad de un cambio violento y revolucionario. Monseñor Romero se desmarcó sistemáticamente de esta posición. "La única violencia que admite el Evangelio -decía- es la que uno se hace a sí mismo. Cuando Cristo se deja matar, esa es la violencia: dejarse matar. La violencia en uno es más eficaz que la violencia en

28. Este brevísimo resumen está tomado de su IV Carta Pastoral. La Carta está publicada en $L a$ voz de los sin voz, Sobrino, J.; Martín-Baró, I. y Cardenal, R., eds., San Salvador, 1980, pp. 125-172. A efectos de la cita ver especialmente pp. 145-148.

29. OR, III, 1980, p. 9. Esta parte del trabajo sobre el pensamiento de Monseñor Romero, en tomo a temas como la violencia, la persecución y el martirio, se me facilitó enormemente gracias a la colaboración de Thomas Greenan, sacerdote escocés con varios años de trabajo en El Salvador, que me entregó buena parte de sus materiales para el trabajo de fin de licenciatura que está haciendo en la Universidad Pontificia de Comillas sobre Monseñor Romero. 
otros. Es muy fácil matar, sobre todo cuando se tienen armas, pero qué difícil es dejarse matar por amor al pueblo"30. Y repitiendo lo mismo, en una referencia directa a las partes involucradas en el entonces preludio de la guerra civil, insinuaba al mismo tiempo caminos de reconciliacion: "Sepan que hay una violencia muy superior a la de las tanquetas y también a la de las guerrillas. Es la violencia de Cristo: Padre, perdónales, que no saben lo que hacen"31. Y ligando el tema de la violencia con el martirio: "La violencia de la no violencia... Decían que los mártires no era que les faltara valor cuando se dejaban matar, sino que desde su situación de víctimas eran más fuertes y ganaban la victoria de los perseguidos" ${ }^{\text {"2 }}$.

\section{La persecución}

En una situación de pecado social estructural, si la Iglesia es fiel a su misión será necesariamente perseguida. Porque "el pecado salta, como la culebra, cuando es apelmazada" ${ }^{\text {"33 }}$. En realidad, la persecución ni siquiera se dirige exclusivamente a la Iglesia o a los cristianos. "La saña de la persecución no es para los hombres sino que termina en Jesús"34. Y es Jesús el que da la fuerza para resistirla, al mismo tiempo que manifiesta el poder de Dios en la debilidad. Por ello, la Iglesia se embellece con las persecuciones: "No olvidemos hermanos, frente a esta ola de difamación de la Iglesia, que la Iglesia es más bella. Se parece a esas rocas del mar que cuanto más las embaten las olas, las embellecen con chorreras de perlas" 35 .
La persecución es nota característica de la Iglesia, porque también fue perseguido su Maestro. De alguna manera le acompañamos y completamos en nosotros, su cuerpo, con profunda esperanza, su pasión. Porque "El no ha pasado solo el túnel doloroso de la tortura y de la muerte; con $\mathrm{El}$ va pasando todo un pueblo, y resucitaremos con $\mathrm{El}^{\prime 36}$. Este compromiso con el Señor lleva a la Iglesia a ser solidaria con aquellos con los que Jesús fue solidario primero. "La Iglesia sufre el destino de los pobres: la persecución. Se gloría nuestra Iglesia de haber mezclado su sangre de sacerdotes, de catequistas y de comunidades con las masacres del pueblo, y haber llevado siempre la marca de la persecución. Precisamente porque estorba, se la calumnia y no se quiere escuchar en ella la voz que reclama contra la injusticia"37.

\section{El martirio}

Monseñor Romero comenzó a hablar del martirio después de la muerte del P. Rutilio Grande. Al principio, tal vez sorprendido por una realidad (la persecución religiosa) que nunca había llegado en El Salvador hasta esos extremos de violencia y muerte, repetía la doctrina tradicional. El martirio es una gracia y por ello "todos debemos estar dispuestos a morir por nuestra fe, aunque no nos conceda el Señor este honor"38. Constata, sin citarlas, las viejas afirmaciones de la Carta a Diogneto, Justino y Tertuliano, en el sentido de que la muerte de los cristianos es "semilla de vocaciones, semilla de cristianismo, semilla de un florecimiento de la Iglesia"39; recuerda que en el martirio hay

30. OR, VI, 1981, p. 170. Aun manteniendo su clara posición personal pacifista, Monseñor Romero reconocía el derecho a la legítima defensa $e$, incluso, en ese marco, a la insurrección con las condiciones tradicionales de la Iglesia. Ver La voz de los sin voz, o.c., p. 158.

31. OR, VI, p. 136.

32. OR, V, 1981, p. 193.

33. En esta comparación quiere decir que así como la culebra salta y se lanza amenazante contra quien la molesta, así es también el pecado. OR, I-II, p. 339. Más adelante, y más explícitamente, dejaba muy en claro que "siempre que se ha denunciado, desde la Palabra de Dios, todos los abusos de los poderes del mundo, surgen las persecuciones" $(V, 264)$.

34. OR, IV, 1981, p. 72.

35. OR, I-II, p. 77.

36. OR, IV, p. 82.

37. OR, VIII, 1989, p. 235.

38. OR, I-II, pp. 44-45. Rutilio Grande murió el 12 de marzo de 1977, y la homilía citada aquí es del 15 de mayo de 1977. 39. OR, I-II, p. 287. 
una victoria de la fe, y que mártir significa ser matado "en odio de la fe" bienaventuranza de Mt 5, 10-11, y pone en parangón martirio con presencia del Espíritu Santo, claro recuerdo para nosotros de cómo comenzó a evolucionar el concepto de martirio: "Una Iglesia tan mártir. Una Iglesia tan llena del Espíritu Santo"41.

Con el paso del tiempo y con el aumento de la muerte en su diócesis, Monseñor Romero comienza a hacer distinciones. Su concepto de martirio comienza a hacerse más histórico. Aunque Monsenor Romero podía interpretar el concepto canónico de martirio con facilidad y rectitud, las acusaciones ante Roma, que después veremos, le llevaban a especificar bien sus ideas sobre temas de posible conflicto. Surge entonces la denominación de "mártires en sentido popular" que Monseñor Romero repetirá incluso 22 días antes de su muerte. Con más de diez sacerdotes asesinados, Monseñor Romero decía: "Son mártires en el sentido popular, naturalmente. Yo no me estoy metiendo en el sentido canónico, donde ser mártir supone un proceso de la suprema autoridad de la Iglesia que lo proclame mártir ante la Iglesia Universal. Yo respeto esa ley y jamás diré que nuestros sacerdotes asesinados han sido mártires canonizados. Pero sí son mártires en el sentido popular. Son hombres que han predicado precisamente esta incardinación con la pobreza. Son verdaderos hombres que han ido a los límites peligrosos de la U.G.B. ${ }^{42}$, donde se puede señalar a alguien y se termina matándolo como mataron a Cristo.
Estos son los que yo llamo verdaderamente justos. Y si tuvieron sus manchas, ¿quién no las tiene, hermanos?... Los sacerdotes que han sido matados también fueron hombres y también tuvieron sus manchas. Pero el hecho de que les quitaran la vida y no haber huído, no haber sido cobardes y haberlos situado en esa situación de tortura, de sufrimiento, de asesinato, para mí es tan valioso como un bautismo de sangre. $Y$ se han purificado. Tenemos que respetar su memoria"43.

Asumir el dolor del pueblo, en su búsqueda de libertad y dignidad, es incorporarse al sacrifico de Cristo. "Los mártires, los héroes de las grandes batallas de la tierra, si han puesto su confianza y su esperanza en Dios, vencerán aun cuando aparentemente no haya más que una muerte silenciosa en el dolor y la ignominia"4.

Y como si presagiara su propio destino, de nuevo 22 días antes de su asesinato, vuelve a hablar del auténtico triunfo de los mártires. Ellos no se han apartado de la historia. Al contrario, están más presentes y son garantía de futuro. Ellos, desde el Reino que "los perfecciona en el amor, siguen amando las mismas causas por las cuales murieron. Lo cual quiere decir que en El Salvador esta fuerza liberadora no sólo cuenta con los que van quedando vivos, sino que cuenta con todos aquellos que los han querido matar y que están más presentes que antes en este proceso del pueblo'ms.

Esta concepción del mártir como persona viva que construye Iglesia y permanece actuando en el

40. OR, IV, p. 211. Para Monseñor Romero, el concepto de odio a la fe le resultaba realmente operativo, pues él estaba convencido que la persecución provenía de un odio a posiciones claramente derivadas del Evangelio y de la fe en Jesucristo. Sin embargo, no todos coincidían con él. Por ejemplo, Monseñor Aparicio, obispo de San Vicente, acusaba sistemáticamente a Monseñor Romero de predicación violenta y subversiva (Ver Romero, O., Monseñor. Su Diario, San Salvador, Febrero de 1990, p. 13).

41. OR, VI, p. 90.

42. Unión Guerrera Blanca, escuadrón de la muerte famoso en aquellos momentos. $N$. del $E$.

43. OR, VII, 1988, p. 287. En tomo a los avisos dados a Monseñor Romero, baste con recordar que tras la Visita Apostólica a la archidiócesis de San Salvador, Monseñor Qarracino, el obispo visitante, recomendó el nombramiento de un administrador apostólico, sede plena, para la misma, lo que habría supuesto el orillamiento de Monseñor Romero. Este tema lo habla con el Papa el 7 de mayo de 1979 (Su Diario, p. 179). Monseñor Romero comentó esta entrevista con el Papa diciendo que "no se debe esperar siempre una aprobación rotunda, sino que es más útil recibir advertencias que puedan mejorar nuestro trabajo" (Su Diario, Ibid.).

44. OR, VII, p. 450. Una semana antes había dicho, también en la homilía dominical y en un contexto referido al martirio, que había que asumir "el dolor como moneda que compra libertad" (Ibid., p. 430). La alusión a "los héroes de las grandes batallas de la tierra" no hay duda que recuerda la cita que hemos hecho de Historia Eclesiástica, V, "Prólogo", p. 4.

45. OR, VIII, p. 295. 
Pueblo de Dios, la desarrolla Monseñor Romero al hablar de su propio y posible asesinato. Aunque en extenso, merece la pena dejarle hablar: "He sido frecuentemente amenazado de muerte. Debo decirle que como cristiano, no creo en la muerte sin resurrección. Si me matan resucitaré en el pueblo salvadoreño. Se lo digo sin ninguna jactancia, con la más grande humildad.

Como pastor estoy obligado, por mandato divino, a dar la vida por quienes amo, que son todos los salvadoreños, aun por aquellos que vayan a asesinarme. Si llegaran a cumplirse las amenazas, desde ya ofrezco a Dios mi sangre por la redención y resurrección de El Salvador.

El martirio es una gracia de Dios que no creo merecer. Pero si Dios acepta el sacrificio de mi vida, que mi sangre sea semilla de libertad y la señal de que la esperanza será pronto una realidad. Mi muerte, si es aceptada por Dios, sea por la liberación de mi pueblo y como un testimonio de esperanza en el futuro. Puede usted decir, si llegaran a matarme, que perdono y bendigo a quienes lo hagan. Ojalá así se convencieran que perderán su tiempo. Un obispo morirá, pero la Iglesia de Dios, que es el pueblo, no perecerá jamás"46.

\section{Aplicación de criterios}

Después de una lectura de las reflexiones sobre el martirio que hacian los Padres de los tres primeros siglos de vida de la Iglesia, el discurso de Monseñor Romero resulta hasta familiar. No es objeto de este trabajo desarrollar los paralelismos más que evidentes entre unas y otras tematizaciones del martirio, sino tra-

Monseñor Romero decía:
"Son mártires en el sentido popular,
naturalmente. Yo no me estoy metiendo
en el sentido canónico, donde ser mártir
supone un proceso de la suprema auto-
ridad de la Iglesia que lo proclame
mártir ante la Iglesia Universal".

do sobre la violencia, la persecución o el martirio, coinciden, a veces incluso en un significativo paralelismo, con citas que hemos hecho de los antiguos mártires y sus "teólogos" del martirio, mártires también muchos de ellos.

Por eso, en vez de recorrer mecánicamente las dimensiones martiriales anteriormente elaboradas, afirmando laudatoriamente que todas se cumplen en Monseñor, creo mejor recorrer las críticas que en su momento se hicieron a Monseñor Romero desde sectores eclesiásticos. Como veremos, estas críticas nos remontan con facilidad a las dimensiones-criterios antes enunciados.

\section{A. Nota previa sobre enfrentamientos eclesiales}

Antes de entrar en este análisis conviene reflexionar brevemente sobre el conflicto eclesiástico y el martirio. Durante los siglos que hemos estudiado hubo con relativa frecuencia enfrentamientos entre cristianos, incluídos obispos, que después murieron mártires. Calixto e Hipólito, o Esteban y nuestro ya conocido obispo Cipriano de Cartago son ejemplos conocidos. Entre estos dos últimos, la discusión versaba sobre si debía rebautizarse o no a aquellos que hubieran sido bautizados en la herejía y que solicitaban la comunión con la Iglesia Católica. Esteban, en lo correcto, pensaba que no sólo no era necesario, sino que no era lícito rebautizar. Cipriano, al contrario, era un ardiente adalid del segundo bautismo. Las cartas que se cruzaron rozaban la excomunión. Sin que se hubieran reconciliado, ambos murieron mártires y ambos son venerados como tales por la Iglesia.

En otras palabras, una medida pastoral con serias implicaciones dogmáticas no fue óbice para que el compromiso fundamental se viviera con la misma dignidad por ambos pastores. El problema, en cambio, puede presentarse cuando se rehuyen compromisos fundamentales. Comparando a Monseñor Romero con sus opositores eclesiásticos es indudable que él cumplió, desde una actitud pro-

46. La voz de los sin voz, o.c., p. 62. 
fundamente cristiana, con su deber de pastorear, proteger $y$ defender a un pueblo cuyos derechos, incluído el de la vida, estaban siendo sacrificados a intereses profundamente egoistas y particulares. Otros prefirieron la huída a mundos espirituales desencarnados y más respetados e, incluso, alabados por aquellos sectores que mezclaban "política, asesinatos y defensa de sus propios intereses económicos en su afán por combatir tanto a la oposición pacífica como a la subversión armada"47.

Al final, y parafraseando a Cipriano, es el Evangelio el que hace a los pastores y no los pastores los que hacen el Evangelio. Y fue el mismo Evangelio, más allá de las divergencias, el que hizo mártires a Esteban y Cipriano. Al final, el único problema grave en la Iglesia sería dejar de amar a los hermanos y rehuir el testimonio público del amor a Cristo, encamado en una historia en la que el rostro del mismo Cristo se refleja de un modo especial en el de los humillados de esta tierra.

\section{B. "Usted está dividiendo al país"}

La primera acusación fuerte, de origen eclesiástico, contra Monseñor Romero se resume con las palabras dichas por Monseñor Aparicio, Obispo de San Vicente, pronunciadas durante la Conferencia Episcopal de El Salvador (CEDES) el 3 de abril de 1978: "Usted está dividiendo al país y confundiendo a la nación"48. Esta acusación, nacida primero en ambientes civiles, fue repetida con frecuencia en algunos ambientes eclesiásticos.

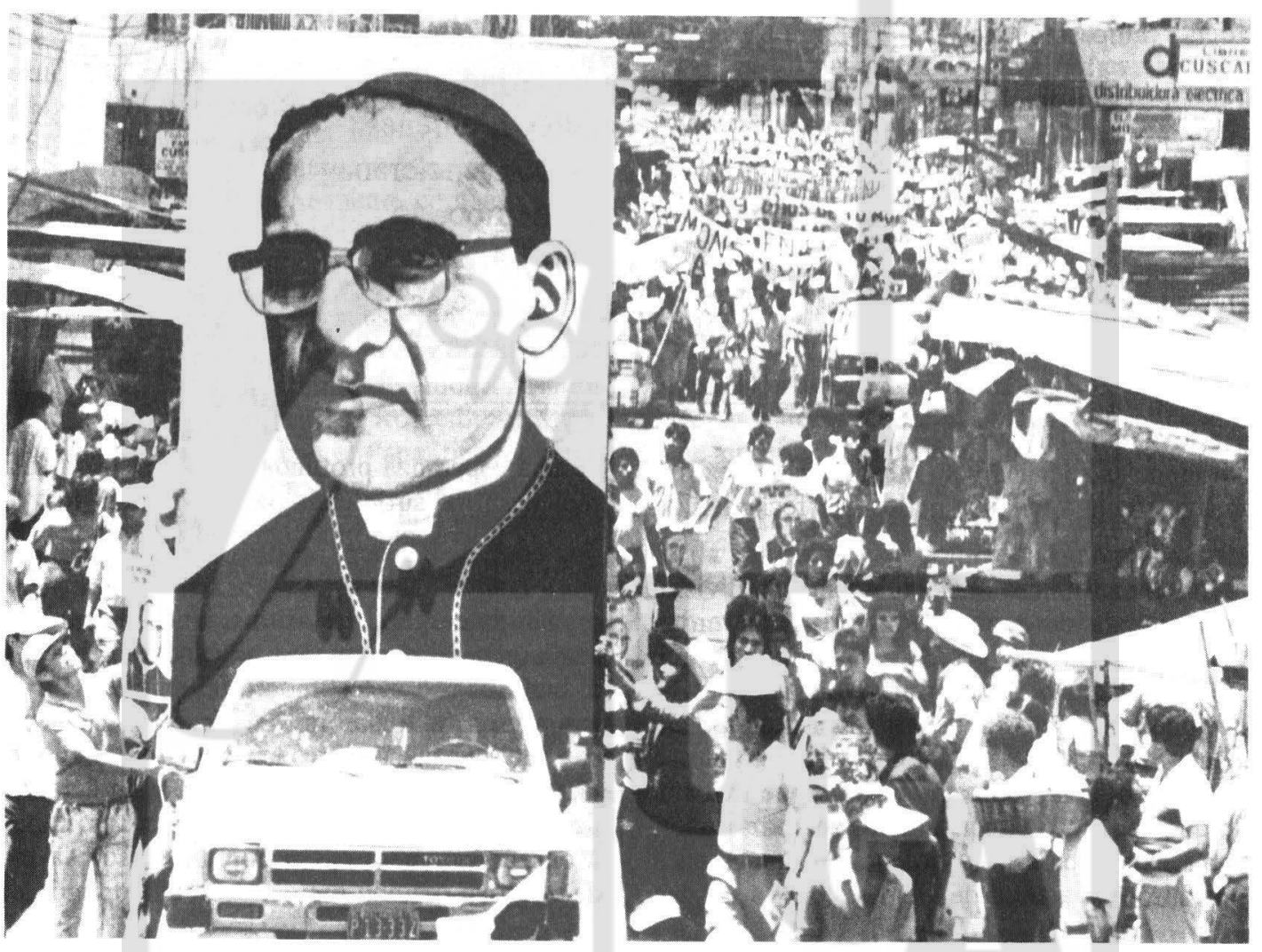

47. De la locura a la esperanza, o.c., p. 142. El informe se refiere aquí a los grupos militares y civiles que componían los "escuadrones de la muerte". El Diario de Hoy, vinculado en su línea editorial a la política de los "escuadrones de la muerte", alabó con frecuencia a los opositores eclesiásticos de Monseñor Romero. Este, en su IV Carta pastoral ya citada, reconocía la división interna en la Iglesia y proponía como camino de unidad la opción preferencial por los pobres. Ver La voz de los sin voz, o.c., p. 137.

48. Brockman, James R. La Palabra queda, Lima, 1985, p. 202. El libro es la primera biografía publicada sobre Monseñor Romero. 
Si esto fuera cierto, con dificultad se podría considerar mártir cristiano a alguien que siembra violencia y que luego es víctima de la misma. Obispos asesinados, e incluso Papas, los hubo durante épocas duras de la Iglesia, y a nadie se le ocurrió declararlos mártires cuando las circunstancias del asesinato mostraban, de ambas partes, víctima y verdugo, un desaprensivo juego de poder, ambición, corrupción moral, o cualquier otro tipo de acciones turbias precedentes.

Sin embargo, el caso de Monseñor Romero fue distinto. La división en la sociedad salvadoreña era previa a su nombramiento como Arzobispo. En 1932, el Ejército había masacrado en diferentes partes del país a una cantidad de campesinos que se suele calcular en 30,000 . El delito era pedir tierras y comenzar un operativo rebelde en el país para tomárselas. A partir de los tempranos años setenta, las tensiones vuelven a agudizarse. No es sólo ya la tierra, sino un sistema de gobierno basado en la corrupción que apoya, sin reservas, las diferencias sociales y se muestra cada vez más represivo frente a todos aquellos que reclaman derechos o libertad.

Monseñor Romero reacciona contra la división en el país tratando de decir dónde está la verdad, tratando de pedir paz y reconciliación construida sobre la justicia y denunciando fuertemente las violaciones de los derechos fundamentales de la persona. Sus escritos, en general, y su actitud personal, en particular, son prueba más que evidente de lo que decimos. Nunca en ellos se podrá encontrar una exhortación a la violencia ni nunca en él se encontró una actitud de alegría frente a las des- gracias del sector que le atacaba. Al contrario, con familias que por su condición social se ubicaban claramente en el sector que más le criticaba, nuestro obispo Romero desplegó una exquisita caridad en momentos en que miembros de la mismas eran secuestrados o asesinados.

\section{La manipulación de una personalidad débil}

Monseñor Freddy Delgado, en un folleto titulado La Iglesia Popular nace en El Salvador ${ }^{49}$, y Monseñor Revelo, en otro folleto de escasa difusión $^{50}$, mantenían la tesis de que Monseñor Romero tenía una personalidad débil. De ahí afirmaban que un grupo de sacerdotes y religiosos pertenecientes a la "Iglesia Popular" tenían prácticamente secuestrado a Monseñor Romero y le obligaban a decir lo que ellos querían.

Evidentemente, si esto fuera verdad, sería muy difícil encontrar en Monseñor Romero coincidencias con las dimensiones martiriales que hemos citado de libertad evangélica, profetismo que nace de una esperanza profunda en el Reino de Dios o reciedumbre suficiente para enfrentar los retos sociopolíticos que una sociedad sumida en el pecado estructural puede presentar.

Sin embargo, estas afirmaciones chocan con el sentir general de sus más cercanos colaboradores e, incluso, con el testimonio de quienes le ayudaban a preparar sus homilías. No era infrecuente el caso de que sus asesores le dijeran el sábado, unánimemente, una serie de ideas sobre un determinado tema, y el domingo se encontraran con que Monseñor Romero en su homilía, desde su modo de ver y su oración previa, daba una opinión dife-

49. Este folleto fue financiado y distribuido por la Fuerza Armada Salvadoreña, a la que Monseñor Freddy Delgado sirvió durante muchos años como miembro del Vicariato Castrense, después de haber sido, en tiempos de Monseñor Romero, Secretario de la Conferencia Episcopal. El título de Monseñor era honorífico.

50. Consulté un ejemplar sin pie de imprenta ni fecha de edición. Circuló más fotocopiado que editado. Publicado parcialmente en El Diario de Hoy, fue utilizado en ocasiones como arma contra sacerdotes y religiosos tachados de izquierdistas. La última vez que lo oí mencionar fue cuando una mano anónima lo colocó en algunos casilleros de los asistentes al Sínodo sobre la Vida Consagrada, efectuado en Roma en septiembre de 1994. 
rente a la que el día anterior se le había aconsejado. Por si esto fuera poco, su diario personal contradice todo atisbo de debilidad de carácter. Hombre sumamente bondadoso, sabía tomar riesgos y soportar, con la auténtica resistencia neotestamentaria, las adversidades con que la realidad le golpeaba. Un hombre débil no hubiera resistido las sistemáticas presiones que desde todas partes, incluso desde el interior de la Iglesia, recibio.

\section{Irregularidades doctrinales}

Cuatro obispos salvadoreños no dudaron en acusar a Monseñor Romero de estar dominado por "la ideología de la Iglesia Popular". "El arzobispo no sólo la permite, sino que él mismo demuestra con su actitud, y más de una vez en sus homilías, que él mismo está inficcionado por aquella ideología"s1. Supuestamente esta "ideología" eliminaba la estructura jerárquica de la Iglesia haciendo que todo reposara en el pueblo, al modo de una democracia política. Esta misma ideología era la que llevaba a Monseñor Romero, según sus detractores, a permanecer en permanente contacto y connivencia con los izquierdistas.

Con el paso de los años.y con el conocimiento de su diario personal, esta acusación cae por los suelos por sí sola. Si algo se puede deducir de la lectura de su diario es el inmenso amor a Jesucristo y a la Iglesia de Monseñor Romero. Al día siguiente de la entrevista con el Papa, que ya hemos mencionado, y que le produjo cierta "depresión", se dirige a la Plaza de S. Pedro "para encomendarme a los grandes Pontífices, que ... han dado tanta inspiración y orientación a mi vida". Cobra nueva "esperanza" tras una conversación con el cardenal Baggio, y recibe, tras una conversación en clave de "dirección espiritual" con Monseñor De Nicoló, "luces muy claras inspiradas en un gran amor a la Iglesia y cómo la virtud, sobre todo la humildad, en estos casos es una llave muy segura para encontrar solución" ${ }^{2}$. Nada más contrario al estilo que se le suele atribuir a la supuesta "Iglesia Popular". Al contrario, Monseñor Romero vivió su "pasión" como un acto de fidelidad a la Iglesia y como un compromiso con su función de Pastor que no abandona a sus ovejas, independientemente de ideologías o posiciones políticas.

\section{E. Desde lo positivo}

La Iglesia suele decir que en los procesos de beatificación es sumamente importante que el pueblo cristiano haya manifestado su devoción hacia aquellos a quienes se atribuyen virtudes heroicas. En el caso de Monseñor Romero es evidente tanto que su recuerdo permanece, como que sigue siendo generador de actitudes cristianas. En las Iglesias se le presenta con frecuencia como testigo de la verdad y el amor y, por supuesto, como persona que sufrió una muerte martirial (su causa de beatificación está introducida). Su nombre preside diversos comités e instituciones que se dedican a la defensa de los derechos humanos y la solidaridad con el Tercer Mundo, así como comunidades cristianas comprometidas con el trabajo de unir fe, justicia y vida. Además de un ingente número de artículos y libros, se han escrito ya tres biografías más sistemáticas en inglés, español e italiano ${ }^{53}$.

Si uno de nuestros criterios martiriales es la dimensión apostólica tras la muerte, no cabe duda que lo anteriormente dicho hay que ubicarlo en este criterio. El hecho de que su sangre se haya transformado en una auténtica semilla que ha ayudado a fortalecer compromisos cristianos en cercanía a los pobres, en solidaridad internacional y en resistencia en el dolor y la esperanza, nos remite a esa dimensión multiplicadora de la que ya hablaba la Carta a Diogneto: “¿No ves cómo son arrojados a las fieras, para obligarlos a renegar del Señor, y no son vencidos? ¿No ves cómo cuanto más se les castiga, más se multiplican otros? Eso no parece obra de hombre. Eso pertenece al poder de Dios; son pruebas de su presencia"s4.

51. Brockman, J. o.c., pp. 321-22. El documento citado es una carta dirigida a Roma por los obispos Aparicio, Alvarez, Barrera y Revelo. En él no sólo acusaban a Monseñor Romero sino que prácticamente hacían pasar a los Padres Rutilio Grande y Alfonso Navarro como renegados de izquierda asesinados por sus antiguos compañeros izquierdistas.

52. Su Diario, o.c., p. 181.

53. Se trata, respectivamente, de las biografías escritas por James Brockman, Jesús Delgado y Ettore Massina.

54. Carta a Diogneto, 7, 7-9, en Padres Apost6́licos, o.c., 853. En concordancia con las últimas frases de esta cita es interesante recordar que el P. Ellacuría, asesinado casi diez años después, solía decir que "con Monseñor Romero, Dios pasó por El Salvador". La frase de Ellacuría estaba dicha en el contexto de la Pascua, el paso del Señor, 
Quienes crecen en su fe ante el obispo mártir, lo ven también como un "calco" historizado de la vida del Señor Jesús. Qué duda cabe, y sus escritos lo demuestran, que en Romero había un profundo deseo de identificarse con Aquel a quien decidió seguir desde muy pronto. Algunos de los textos que hemos citado lo dejan entrever muy claramente.

Es difícil decir cuáles han sido, entre las diversas dimensiones martiriales que anteriormente hemos expuesto, las más características de Monseñor Romero. A mi juicio, sin embargo, las que hemos llamado dimensiones sicológicas ${ }^{55}$ son las más señeras en este arzobispo. La libertad evangélica y la resistencia definen su conducta. Su claridad en el hablar, incluso pidiendo a los soldados que desobedecieran a sus superiores si éstos les daban, contra toda legalidad, la orden de matar, le valió la muerte $^{56}$. Pero antes, su resistencia a presiones, amenazas, incompresiones y calumnias, lo hizo aparecer, utilizando términos tomistas relacionados con el martirio, eximio ya, antes de la muerte, en la virtud de la fortaleza. En el comunicado de la Conferencia Episcopal que siguió a su muerte, se le describe (por fin) con las virtudes del "fuerte" y del profeta: "Fiel a su lema de decir la verdad para construir la paz fundamentada en la justicia, anunció incansablemente el mensaje de Salvación y denunció con vigor implacable la situación de injusticia institucionalizada y los abusos en contra de los derechos humanos y de la dignidad inalienable del hombre, hecho a imagen y semejanza de Dios. Esto le mereció el aprecio de propios y extraños, pero también suscitó la aversión de los que se sentían incómodos por la fuerza de su palabra evangélica y de su testimonio. Por ser fiel a la verdad cayó como los grades profetas entre el vestíbulo y el altar"s7.

Aunque para nuestro trabajo es más importante constatar el cumplimiento de los criterios martiriales que hemos expuesto, no es malo tampoco hacer una referencia al odio de los perseguidores. Hoy nadie duda de la buena voluntad del arzobispo. Quienes persisten en sus acusaciones, hoy sólo se atreven a decir que fue manipulado o que carecía de prudencia en algunos aspectos. Nadie niega su amor a Cristo, su sentido eclesial y su amor al pueblo salvadoreño. Los valores cristianos que predicó se ceñían a las necesidades prioritarias del pueblo: respeto a la vida, justicia social, fe en Dios y conversión frente a las idolatrías del dinero, del poder y de la organización, oprimentes y opresoras al mismo tiempo. El odio de sus perseguidores, aunque no le demos excesiva importancia al criterio, fue un odio genuino a los valores que en cuanto hombre de Dios expresaba. Es cierto que sus valores cristianos tenian una determinada repercusión política. Pero esa dimensión es también la que hemos encontrado en los primeros mártires, reos de impiedad contra el Imperio Romano y sus Emperadores. La dimensión política, como ya hemos visto, si está enclavada en los valores evangélicos no hace a los "degollados" menos mártires, sino que se convierte en una dimensión esencial de su sacrificio ${ }^{58}$. No en vano "el tiempo de la Bestia", "es para los santos la hora de la resistencia - ypomone- y de la fe" (Ap 13, 9).

Si los escuadrones de la muerte hubieran dado una sentencia, no hubiera sido muy diferente de la que determinó la muerte de San Cipriano, muchos

y no recordando a los Santos Padres, pero la coincidencia tan cercana con lo que dice la Carta a Diogneto no deja de ser fruto de una experiencia muy semejante.

55. Aunque estas cualidades son llamadas en mi clasificación dimensión sicológica, no trato de definir desde la ciencia unos rasgos caracteriológicos en general. Creo que la fe produce una transformación, con frecuencia, de la propia sicología, incluso poniendo fortaleza en la debilidad y libertad en medio de la angustia. La dimensión sicologica se refiere especialmente a esa dimensión de fe en la que la propia sicología queda invadida y potenciada por la fuerza del Espíritu.

56. "Yo quisiera hacer un llamamiento de manera especial a los hombres del Ejército... Ante una orden de matar que dé un hombre, debe prevalecer la ley de Dios que dice: No matar... ningún soldado está obligado a obedecer una orden contra la ley de Dios... En nombre de Dios, pues, y en nombre de este sufrido pueblo cuyos lamentos suben hasta el cielo cada día más tumultuosos, les suplico, les nuego, les ordeno en nombre de Dios: Cese la represión" (Homilía del 23 de marzo de 1980, víspera de su muerte, citada por Bronckman J. La palabra queda, o.c., p. 424).

57. Brockman, J. o.c., p. 432 (las cursivas son mías).

58. Cuando hablamos de dimensión política lo hacemos en su sentido amplio, como ya hemos expresado. A propósito de la visita del Arzobispo de Maracaibo en diciembre de 1979, que le transmitió un mensaje del Presidente de 
años atrás. Bastaría con haber cambiado las referencias a los dioses romanos por los ídolos del poder y del dinero que Monseñor había denunciado: "Durante mucho tiempo has vivido sacrílegamente y has juntado contigo en criminal conspiración a muchísima gente, constituyéndote enemigo de los dioses romanos y de sus sacros ritos, sin que los piadosos y sacratísimos príncipes Valeriano y Galieno, augustos, y Valeriano, nobilísimo César, hayan logrado hacerte volver a su religión. Por tanto, convicto de haber sido cabeza y abanderado de hombres reos de los más abominables crímenes, tú servirás de escarmiento a quienes juntaste para tu maldad, y con tu sangre quedará sancionada la ley"59.

\section{Los jesuitas de la UCA}

El 16 de noviembre de 1989 , a eso de las 8 de la mañana, Monseñor Rivera Damas hacía, frente a los cadáveres de los jesuitas, y después de haber rezado ante ellos, el primer comentario ante los medios de difusión que lo acosaban: "Los mató el mismo odio que a Monseñor Romero". Conociendo al Arzobispo y sabiendo la admiración que profesaba a su antecesor en el gobierno de la archidiócesis, no cabe duda que fue una primera calificación de la muerte de los jesuitas como acontecimiento martirial. Una segunda (entre muchas otras segundas) la hizo, también con ese su modo semielíptico, durante la Misa del décimo aniversario de la muerte de Mon- señor Romero, pocos meses después. Durante esta Eucaristía, Monseñor Rivera anunció la introducción a nivel diocesano de la causa de beatificación de su antecesor. Hubo una gran cantidad de obispos invitados y una significativa presencia del pueblo salvadoreño.

Pues bien, entre las lecturas iniciales previas a la Palabra, la mayor parte sobre Monseñor Romero, se leyó también, parcialmente, la homilía que el Cardenal Silvestrini tuvo en Roma, en diciembre de 1989, durante una Misa concelebrada con Monseñor Rivera en la Comunidad de S. Egidio. El texto, entre otras cosas, y refiriéndose a los recién asesinados jesuitas, decía: "Tenemos que llamarlos mártires ya. No podemos esperar cincuenta años".

Al final de nuestro recorrido por el tema del martirio nuestra reflexión será muy breve. Baste en ella recorrer lo que decía el informe de la Comisión de la Verdad ya citado, y unas mínimas consideraciones posteriores.

\subsection{Los hechos ${ }^{60}$}

El asesinato de los jesuitas es, en el informe que manejamos, el caso ilustrativo del capítulo titulado "Violencia contra opositores por parte de agentes del Estado". En él se narra, como antecedente, la identificación que representantes del Ejército hacían sistemáticamente entre los jesuitas y los subversivos. Y se explica la razón de esta

Venezuela ("en qué pueden ayudar a la difícil situación de El Salvador"), Monseñor Romero reflexionaba en su diario: "Yo decidí que actuaría como Pastor, como siempre he tratado de hacerlo... desde el punto de vista pastoral, sólo pediría la influencia internacional para suavizar los extremismos de izquierda y de derecha y, tal vez, mandar ayudas políticas a los diferentes partidos de nuestro pais, pero esto pertenecía al campo de la política. Mi afán como pastor es buscar la unidad, suavizar tanta violencia y que si en este sentido algo podrían hacer, sería, pastoralmente, una verdadera colaboración con la Iglesia que mucho agradeceríamos" (Su Diario, o.c., p. 361). Quienes tenían construida buena parte de su política sobre la violencia, no dejaban de ver esta actitud como una politización eclesiástica.

59. “Actas del Martirio de San Cipriano”, IV, en Actas de los Mártires, o.c., pp. 759-60.

60. En este apartado recorreremos brevemente los hechos según el informe De la Locura a la Esperanza, ya citado. Tenemos también en el contexto a Doggett, Marta, Una muerte anunciada, San Salvador, 1994; Armada, Pedro y Doggett, Marta, Una muerte anunciada en El Salvador, Madrid, 1995; y Whitfield, Teresa, Paying the Price, Filadelfia, 1994. 
animadversión de la Fuerza Armada: "El P. Ellacuría tuvo un rol importante en la búsqueda de una solución negociada y pacífica al conflicto armado. La idea de sectores de la Fuerza Armada de identificar a los sacerdotes jesuitas con el FMLN provenía de la especial preocupación que dichos sacerdotes tenían por los sectores de la sociedad salvadoreña más pobres y más afectados por la guerra. En dos oportunidades anteriores en el mismo año 1989 estallaron bombas en la imprenta de la universidad"61.

Los días 11 y 12 de noviembre, y en el marco de una ofensiva del FMLN lanzada contra la capital, a través de una cadena nacional de radio controlada por el Gobiemo, se lanzaron al aire repetidos y sistemáticos mensajes, a través de llamadas telefónicas, incitando al asesinato de los jesuitas de la UCA y de Ellacuría en particular. El lunes 13 de noviembre, la casa de los jesuitas fue registrada y el 16, a las dos de la mañana, se les asesinó junto con la cocinera de los estudiantes jesuitas de teología y su hija, que estaban alojadas en la sala de visitas de la residencia jesuítica ${ }^{62}$.

Tras su muerte, el Estado organizó una amplia red de propaganda, dentro y fuera del país, con el fin de negar cualquier posibilidad de complicidad en el asesinato, y de insinuar la posible autoría del FMLN en el mismo ${ }^{63}$. Finalmente, y tras la presión internacional, así como forzados por las primeras declaraciones de un oficial norteamericano que acusaba al Coronel Benavides como autor de los hechos, se abrió el caso que culminó con la condena legal del coronel mencionado y de un teniente. La Comisión de la Verdad afirma en su informe, y da los nombres de ellos, que el Jefe del Estado Mayor Conjunto de la Fuerza Armada, "en confabulación" con otros cuatro oficiales de alta graduación (dos de ellos Viceministros de Defensa, y otro Jefe de la Fuerza Aérea) "dio... la orden de dar muerte al sacerdote Ignacio Ellacuría sin dejar testigos"64. Para la Comisión existe además "plena prueba" de que otros cuatro militares de alta graduación participaron activamente en el encubrimiento del asesinato, así como al menos un miembro de la Comisión de Honor Presidencial que se formó para hacer una breve investigación sobre el caso en el interior del ejército.

\subsection{Mártires intelectuales}

Aunque los hechos son excesivamente escuetos no añadimos nada a lo dicho, porque entrar en los antecedentes del crimen para demostrar la calidad martirial de los asesinados nos llevaría a la redacción de un nuevo trabajo. Nos limitaremos ahora a describir, en la clave de las dimensiones que hemos establecido previamente, algunos elementos que nos hacen pensar en los jesuitas como auténticos mártires.

Así como al hablar de Monseñor Romero mencionamos al obispo Cipriano, la figura de los jesuitas nos recuerda en primer lugar la de S. Justino, aunque su pensamiento sea tan diferente y las épocas tan alejadas.

Como Justino, los jesuitas fueron intelectuales que amaban profundamente la verdad. Como el, fueron convertidos por la resistencia y el coraje de la gente sencilla, de las comunidades cristianas, de las organizaciones populares que también "iban

61. De la locura a la esperanza, o.c., p. 46.

62. Elba Ramos y su hija se habian refugiado en la residencia de los jesuitas tratando de protegerse, pues varias bombas y disparos habian estallado en las inmediaciones de su casa el 11 de noviembre. Amando López las había alojado en la sala de visitas. Ambas se sumaron al martirio por el único delito de ser testigos del crimen. Evidentemente quienes habian dado la orden de matar estaban convencidos de que cualquier testigo cercano a los jesuitas no podría ser silenciado más que con la muerte. Se presuponía, pues, una rectitud moral en las personas, no plegables a la mentira urdida por los asesinos, y por ello se las mataba.

63. Delegaciones de alto nivel político fueron enviadas a los países con mayor relación económica y diplomática con El Salvador. El gobierno salvadoreño incluso financió un viaje a Roma de los obispos Revelo y Tovar, junto con el Secretario de la Conferencia Episcopal de El Salvador (CEDES), Leopoldo Barreiro, antiguo y actual capellán castrense. En Roma, esta delegación repartió en diferentes dicasterios un informe no firmado, pero escrito en papel oficial de la CEDES, en el que se acusaba a los jesuitas de no colaborar con la investigación gubernamental, y a Monseñor Rivera de obstruir la investigación lanzando "acusaciones temerarias" contra la Fuerza Armada. Monseñor Tovar hizo declaraciones (publicadas con el titular Cui prodest) a Treinta Dias, enero, 1990, insinuando la culpabilidad de la guerrilla en el asesinato y diciendo claramente que no estaba de acuerdo con las acusaciones contral el ejército de Monseñor Rivera.

64. De la Locura a la esperanza, o.c., p. 50. 
intrépidamente a la muerte"6s defendiendo sus derechos y su dignidad, muchos de ellos desde sus convicciones cristianas. Ellacuría no dudaba en decir, a partir de su experiencia entre los pobres de El Salvador, que "estos despojos (se refiere a los despojados de este mundo), en cuanto son llenos del Espíritu y buscan no su instalación personal en el banquete de este mundo, sino la desaparición de las condiciones reales del despojo violento, son el verdadero pueblo que, movido por el Espíritu de Cristo, puede llevar adelante la salvación histórica y con ella la liberación"66. Así como los primeros cristianos evangelizaron a Justino, así los "pobres con Espíritu", evangelizaron a los jesuitas y los incorporaron a su causa. Ellos fueron los rostros vivientes e historizados de Jesús que condujeron, a Ellacuría y compañeros, a la identificación suprema con el Señor en la muerte injusta y violenta.

Como Justino, los jesuitas trataban de ver la realidad en su totalidad. Justino es el primero en afirmar desde elementos filosóficos, entre los primeros cristianos, la unidad de la creación. El logos spermatikós (semillas del Verbo) sirve a Justino para ver con buenos ojos todo aquello que en la realidad creada tiende al encuentro con su Creador. Para él, Sócrates y Heráclito erán de alguna manera cristianos antes de Cristo, vivieron en conformidad con la verdad (con la razón, el logos) y trataron de establecerla en la tierra. También ellos fueron "tenidos por ateos" y perseguidos por los que "vivieron sin razón..., (que son) asesinos de quienes viven con razón"

Los jesuitas veían también cuanto de bueno encontraban a su alrededor, trataban de dialogar con ello y usaban la razón como arma. Siendo fuerza de la razón, fueron golpeados por la razón de la fuerza y por la idolatría del poder que antes denunciara Monseñor Romero. El anuncio y la denuncia se mezclaban, como en Justino, con el claro pacifismo de quien confía más en la verdad como fuerza histórica que en la retórica de la violencia.

El análisis de la realidad es otro elemento común entre estos intelectuales, tan alejados en el

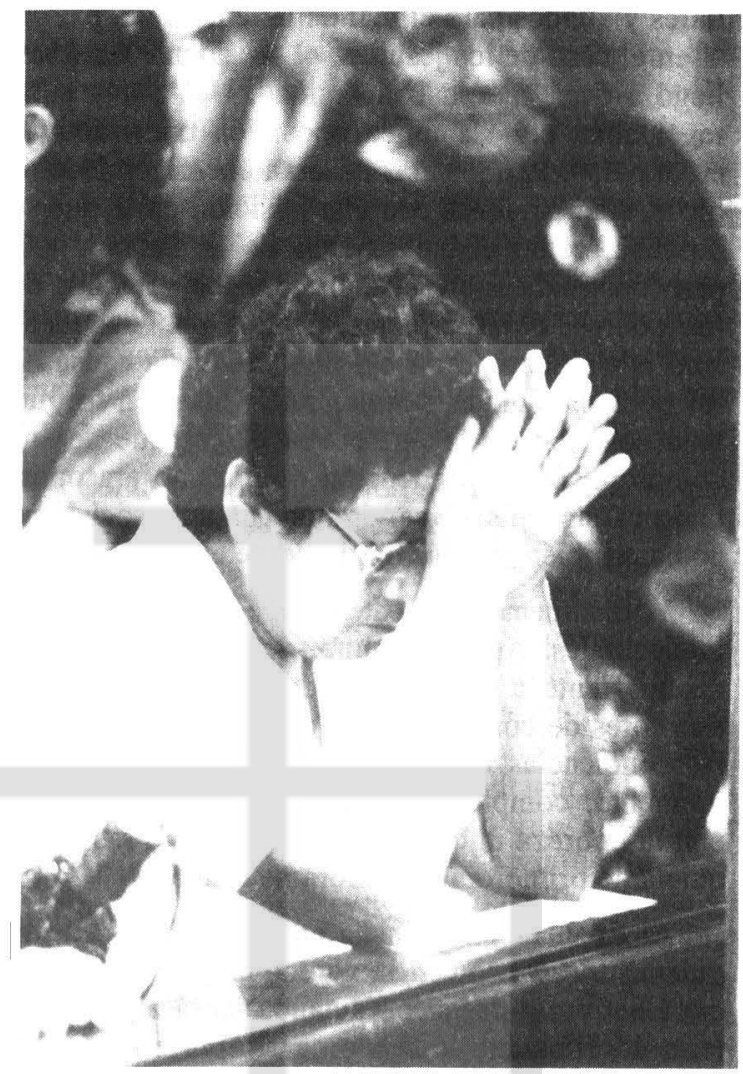

tiempo. Justino analiza el por qué de las idolatrías. Y en una síntesis apretada, y en algunos momentos barroca y compleja, va identificando ídolos con demonios, idolatría con el mal en lucha contra el bien, idolatría con sin razón. El por qué de las persecuciones preocupa a Justino profundamente, como también preocupa a los jesuitas la opresión del pobre, verdadera persecución en tantos aspectos: "La realidad de nuestro mundo... no es sino la existencia de una gran parte de la humanidad literal e históricamente crucificada por opresiones naturales y, sobre todo, por opresiones históricas y personales"68.

Justino no dudaba en decir a los emperadores que los cristianos "somos vuestros mejores auxi-

65. Justino, Apología Il, 12, 1, en Padres Apologetas, B.A.C., Daniel Ruiz Bueno (ed), p. 274. Justino nos cuenta en este pasaje su conversión al cristianismo viendo el ejemplo de los cristianos. Ese ir intrépidamente a la muerte era para Justino incompatible con vivir "en la maldad".

66. Ellacuría, I. Conversión de la Iglesia al Reino de Dios, Santander, 1984, p. 77.

67. Apología 1, 46, 3-4 en Padres Apologetas, o.c., p. 233.

68. Ellacuría, I. Conversión de la Iglesia al Reino de Dios, o.c., p. 25. En este contexto es curioso recordar que Justino decía que la única realidad que los demonios no podían subvertir, dentro del orden religioso, era la cruz 
liares y aliados para el mantenimiento de la paz"69. $Y$ en el caso de los jesuitas, el presidente Cristiani llegó a decir que la Universidad, UCA, que ellos regentaban era "la única oposición constructiva" en el país ${ }^{70}$. Los jesuitas no eran enemigos ideológicos, sino personas con una posición en la que se buscaba, como el bien mayor de El Salvador, la paz construida sobre el diálogo y los derechos de los pobres. No fueron asesinados por sus ideas sino por su compromiso personal con la causa de los pobres. Aunque, por supuesto, tuvieran formulado con gran rigor intelectual el por qué de sus compromisos. La dimensión política no era oportunismo, sino afán de servir a un conjunto social que podía, también, ser purificado desde el Evangelio.

$Y$, finalmente, el debate vuelve a unir a nuestros intelectuales. Apologeta uno, defensor del cristianismo frente a la sinrazón de los perseguidores, escritores de combate otros, dispuestos a inquietar las conciencias de todos aquellos que viven alegremente, cómplices conscientes o inconscientes con la pobreza injusta que domina como rasgo inquietante primordial el panorama mundial.

Al final, la sinrazón, la envidia y la cólera de quienes traficaban con la verdad en propio beneficio (Justino, y después Taciano, acusa a Crescente, seudofilósofo, de ser la causa, por envidia, de su condena) acaba con la vida de nuestros filósofos cristianos de modo muy semejante. Si el odio del nombre fuera una condición de autenticidad para el martirio (recordemos que Justino fue el primero en denunciar el odio contra el nom- bre de cristiano ${ }^{71}$ ), habría que reconocer también que Ellacuría y compañeros lograron que el nombre de "jesuitas" fuera odiado genéricamente por los perseguidores.

Y es que la pasión por el Reino de Dios convertía a Ellacuría y sus compañeros en personas profundamente libres, a veces incluso demasiado, a juicio de algunos eclesiásticos. Hoy podemos decir de ellos lo que Minucio Félix ponía en boca de un pagano al hablar de la religión cristiana: "levantó su libertad contra los reyes y los príncipes, y sólo la entregó a Dios, a quien pertenecía"7z

Se podrá decir que esta comparación con Justino no prueba los rasgos martiriales que hemos expuesto como elementos para discernir la autenticidad de un martirio. A mi juicio se trata de todo lo contrario. Los mártires encaman en la historia, cada cual a su manera y según su trabajo y vocación en la vida, los rasgos martiriales apuntados. Quien lea con atención los escritos de Justino y el testimonio sobre su muerte ${ }^{73}$, verá en ellos rasgos de un estilo de vida muy especial. Filósofo entre filósofos, con teorías a veces caprichosas, pero amante siempre de la verdad. En los jesuitas de la UCA, más allá de las acusaciones de que puedan haber sido objeto, hay siempre una pasión por la verdad de la realidad y una capacidad de compromiso ante la misma, que no difiere al final del recio estilo de Justino. Las diferencias son, por supuesto, muchas, pero no las suficientes para romper la trayectoria de vidas entregadas a lo que se consideraba un servicio a los perseguidos de su

(Apologia I, 55, 2). Para Ellacuría, los pueblos crucificados eran la realidad primordial, éticamente hablando, que nadie tampoco podía desleir en el concepto encubridor.

69. Apología 1, 12, 1, en Padres Apologetas, o.c., p. 191.

70. En Paying the price, o.c., pp. 329-345, se puede encontrar un resumen del acercamiento, en tomo al tema de la paz, entre el Presidente Cristiani y los jesuitas de la UCA. Acercamiento que no fue óbice, después, para que el Presidente Cristiani fuera uno de los puntales decisivos del encubrimiento que siguí al asesinato de los jesuitas. Sobre el encubrimiento realizado por el gobiemo de Cristiani puede leerse, a modo de ejemplo, el artículo " $\mathrm{La}$ comision de la verdad para El Salvador" de Thomas Buergenthal en la Revista Estudios Centroamericanos, $E C A$, No 563, 1995, especialmente las pp. 827-830, en las que se narran las presiones gubernamentales tratando de impedir que en el informe figuraran nombres de personas.

71. "A nadie que sea acusado ante vuestros tribunales le castigáis antes de que sea convicto; pero tratándose de nosotros tomáis el nombre como prueba (en contra), siendo así que si por el nombre va, más bien debiérais castigar a nuestros acusadores. Porque se nos acusa de ser cristianos que es decir buenos" (Apología I, 4, 4-5). Ver Padres Apologetas, o.c., p. 185.

72. Felix, Minucio. Octavius, XXXVII, PL 3, p. 353.

73. Su muerte puede encontrarse descrita en el "Martirio de S. Justino y sus compañeros", en Actas de los mártires, o.c., pp. 311-316. El cronista pone en boca de Justino las palabras: "Nuestro más ardiente deseo es sufrir por amor de nuestro Señor Jesucristo". Martín Baró había mencionado meses antes de su muerte, asumiéndolo como parte de su compromiso cristiano, su convicción de vivir en un ambiente en el que prevalecía "la posibilidad de ser asesinado en cualquier momento del día" (Paying the Price, o.c., p. 334). 
tiempo desde la reflexión y el pensamiento. Cuando la memoria histórica recuerde, pasado el tiempo a los jesuitas asesinados, los recordará por algo muy parecido a lo que hoy recordamos de Justino: por su apología de los pobres y perseguidos de $\mathrm{El}$ Salvador y del mundo entero.

\subsection{La motivacion de fondo}

Como testigo presencial de su vida en los últimos años, no me cabe duda que la motivación de los jesuitas asesinados, en su trabajo por la paz, en su labor universitaria y en su acompañamiento de comunidades religiosas y campesinas, cuando el tiempo se lo permitía, nacía de su fe en el Dios del "Reino"". Y surgía también de su interiorización e historización del carisma jesuítico que ve en el "ayudar a las ánimas" la "Mayor Gloria de Dios" en esta tierra, y que busca siempre "el bien más universal" "7s. Con frecuencia repetían que en la situación de emergencia en la que vivía el país "salvar vidas" era más importante que todo lo demás. Y por ello ponían la universidad al servicio sistemático de la paz, de la justicia y de los derechos humanos, especialmente de los derechos de los pobres, que eran los que más sufrían.

Ellacuría gustaba de decir provocativamente que eran parciales, pero no por gustos ideológicos, sino porque la misma realidad era parcial. Eran los pobres los que más sufrían y era el gobiemo el que más mataba. La Comisión de la Verdad, en su análisis de la violencia en El Salvador, les dio $a$ posteriori una razón difícil de negar desde el principio y sólo disputada por el poder encubridor de quienes dominaban mecanismos capaces de manipular los medios de comunicación ${ }^{76}$. Su parcialidad estaba en línea con la parcialidad profética del Antiguo Testamento, que dibujaba a un Dios parcial en favor de los pobres. $O$ de la misma parcialidad que nos muestran las señales del Reino (Lc 4, 16-22).

Como fundamento vital de la acción desempeñada por los jesuitas asesinados, se puede citar, refiriéndolo a todos ellos, lo que Jon Sobrino, sobreviviente casual de la masacre, decía de Ellacuría: "Si algo me llamó poderosamente la atención en Ellacuría desde el principio fue su pasión por el servicio. Su pregunta fundamental, transcendental, diríamos, fue siempre la de qué tengo que hacer, mediación histórica del buscar siempre la voluntad de Dios y cumplirla, tan típicamente ignaciana. Su pregunta en el hacer cotidiano... era también la de S. Ignacio: a donde voy y a qué. Y la esencia de ese hacer fue, por último, servir, esencial también al ideal ignaciano de en todo amar y servir... Y no sólo dedicó su vida a servir, sino que a lo largo de toda ella fue preguntándose qué significaba en concreto ese servicio al que se sabía llamado. Y paulatinamente llegó a comprenderlo no como cualquier

74. El "Reino" era para Ellacuría y para sus compañeros el concepto fundamental que definía el compromiso cristiano y en el que debía enmarcarse cualquier eclesiología. Ver Menéndez, en Rasgos ignacianos de una eclesiología martirial, Maresa 62, 1990, p. 67, dice: "Ellacuría señala algunas características de este Reino de Dios, misión fundamental de la Iglesia. En sus mismas palabras — que hoy nos resultan proféticas — hay pasión por un compromiso de la Iglesia en la historia, al lado de los pobres, que entrañará necesariamente persecución. En el horizonte ignaciano del seguimiento de Jesús, que pide como gracia 'pasar todas injurias y todo vituperio y toda pobreza... por más en ellas le imitar', la persecución está no sólo como posibilidad conscientemente aceptada, sino como deseo expresamente formulado y convertido en oración. A esta luz ha de explicarse no sólo su pensamiento al respecto, sino, lo que es más importante, su radical postura personal".

75. Cuando enviaba gente al trabajo apostólico, San Ignacio insistía en tener "ante los ojos como regla para enderezarse, el mayor servicio divino y bien universal", porque como dirá más adelante, "el bien, cuanto más universal es más divino" (Constituciones de la Compañía de Jesús, Parte VIl, cap. 2, 1, D).

76. "La Comisión de la Verdad registró más de 22,000 denuncias de graves hechos de violencia ocurridos en El Salvador durante el período de enero de 1980 a julio de $1991 \ldots$ los testimoniantes atribuyeron casi 85 por ciento de los casos a los agentes del Estado... Las denuncias registradas responsabilizaron aproximadamente en el 5 por ciento de los casos al FMLN" (De la Locura a la esperanza, o.c., p. 41). Estos datos reflejan una realidad 
servicio, sino como un servicio específico: bajar de la cruz al pueblo crucificado"r .

\subsection{Reflexión final}

Identificación con Jesucristo, creación de Iglesia, valores cristianos encamados en la realidad histórica, anuncio del Reino, denuncia del antirreino, dimensión política del compromiso cristiano, opción pacífica por la transformación de este mundo, libertad y resistencia como actitudes frente a la realidad, dimensión apostólica de la vida y de la muerte, son los rasgos que mencionábamos como característicos de los mártires del pasado. Desde su especificidad personal se dieron también en los jesuitas como en tantos otros muchos.

Las acusaciones de complicidad con los asesinatos de la izquierda, de implicación política, de rebeldía sistemática frente a la autoridad, quedan cada vez más arrinconadas, como han quedado arrinconadas las acusaciones de orgías y convites de Tiestes que se hacían a los primeros cristianos. La muerte pacífica, intrépida, como decía Justino, "aquella libertad esclarecida, que donde supo hallar honrada muerte, nunca quiso tener más larga vida"78, se impone al observador de buena voluntad. Y sus vidas, a la luz de su muerte, cobran un nuevo resplandor que los identifica con el Cordero que, a pesar de haber sido sacrificado, permanece de pie (Ap 5, 6). De nuevo, el criterio apostólico nos habla de la autenticidad de su martirio. Los jesuitas asesinados, en efecto, contribuyeron desde su muerte cargada de sentido, a una aceleración de las conversaciones de paz, a una presión internacional más fuerte en favor de la misma paz y a una puesta sobre el tapete, nuevamente, de los muertos injustamente a lo largo de la guerra ${ }^{79}$.

Los mártires de hogaño sí hacen nido en los martirios de antaño. Con las diferencias obvias de época histórica, el espíritu es el mismo y las idolatrías con que se enfrentan son muy semejantes. Que sean, al respecto, unas palabras de Monseñor Romero las que cierren este trabajo: "El cristiano adora ese Dios en Cristo nuestro Señor. Y si por rechazar idolatrías falsas tiene que morir por ser fiel a su único Dios, Dios lo resucitará. Tenemos gracias a Dios, páginas de martirios no solamente en las historias pasadas, sino en la hora presente"so.

sistemáticamente negada por los gobiernos salvadoreño y norteamericano. Los mecanismos de encubrimiento de la verdad que ambos pusieron en marcha recurrieron con frecuencia a la mentira y al insulto y calumnia de todo el que describía la realidad en su dureza y crueldad. Documentos desclasificados del Departamento de Estado norteamericano, con frecuencia firmados por embajadores, nos ofrecen repetidas calificaciones de izquierdistas referidas a los jesuitas de El Salvador.

77. Sobrino, J. Revista Latinoamericana de Teología, 32, 1994, p. 134.

78. De Quevedo, Francisco. Epístola Satírica y Censoria contra las costumbres presentes de los Castellanos en "Poemas Escogidos", José Manuel Blecua, Madrid, 1987.

79. Entre las presiones intemacionales directamente relacionadas al caso que influyeron en la negociación de la paz hay que mencionar la "Comisión Moakley", del Congreso de Estados Unidos, que fue singularmente activa y puso en muchos aspectos al GOES en el temor de la suspensión de la vital ayuda militar norteamericana. También la continua actividad de la diplomacia española reclamando una investigación más a fondo de la autoría intelectual tuvo un efecto positivo. La impunidad en la que se pretendía quedara el crimen, creó conciencia en mucho de lo nefasto que sería, para una sociedad en proceso de reconciliación, que se ignoraran las responsabilidades tenidas en las campañas de terror y asesinato que habían asolado al país durante más de una década. De este modo, también renovando la tragedia histórica de tanta muerte impune, el asesinato de los jesuitas contribuyó a que se formara una Comisión de la Verdad de cuyo trabajo hemos ya hablado.

80. OR, VI, p. 299. 